\title{
The Impact of the Russian Military System on Nineteenth Century Russian Expansionism in the Caucasus And Central Asia
}

by

Scott Eaton

A thesis submitted to the Faculty of Graduate and Postdoctoral Affairs in partial fulfillment of the requirements for the degree of

Master of Arts

in

European, Russian and Eurasian Studies

Carleton University

Ottawa, Ontario

(C) 2014, Scott Eaton 


\begin{abstract}
This work explores the Russian military system after the Napoleonic Wars, and the impact the military ideologies developed therein had on Russian expansionist efforts in two separate conflicts. The Russian conquests of the Caucasus and Central Asian regions are the expansionist efforts under focus, and specifically battles at Dargo in the Caucasus and Khiva in Central Asia are analyzed. It is argued that, due to a Russian military system that refused to move away from Napoleonic era tactics and ideas, the conquest of the Caucasus was a far more difficult endeavor than the Russian seizure of Central Asia, where largely similar tactics were employed. The established Russian military system created a military that was ill-suited for combat in the Caucasus, and disabled its ability to learn from that conflict. This same system was equally responsible for allowing the Russians to easily defeat their enemies in a Central Asian setting.
\end{abstract}




\section{Acknowledgements}

I would like to thank my longtime teacher and supervisor, Dr. Jeff Sahadeo, for encouraging me to undertake an education at EURUS, for having the subsequent patience to deal with me for all these years, and for encouraging me to study a subject I was interested in rather than what I would regret. I would also like to thank Olga, my favorite TA, who continues to teach me every day. 


\section{Table of Contents}

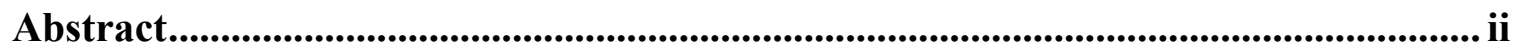

Acknowledgements .........................................................................................................ii

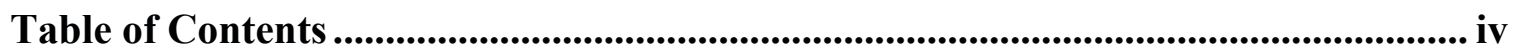

Chapter 1: Introduction .................................................................................................................. 1

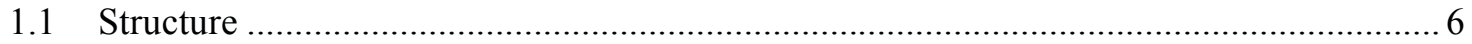

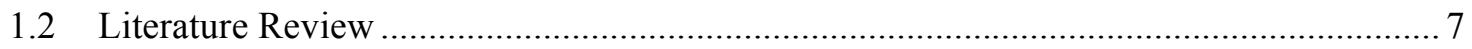

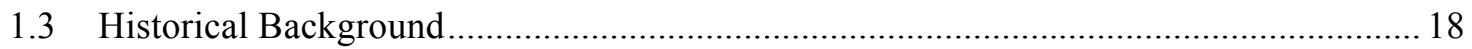

Chapter 2: Russian Military Theory, Strategy, and Politics and Their Impact on Military Performance ................................................................................................................ 25

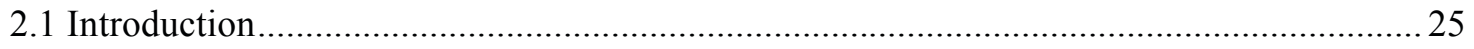

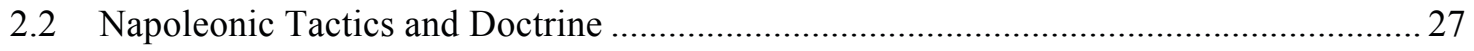

2.3 High Level Organizational Issues …………………………………………………... 30

2.4 The Impact of Serfdom and Societal Issues on the Military System ............................... 33

2.5 The Stagnation of nineteenth century Russian Military Thought and Academics............ 35

2.6 The Results of The Russian Military System and the Napoleonic Dynamic: M. S.

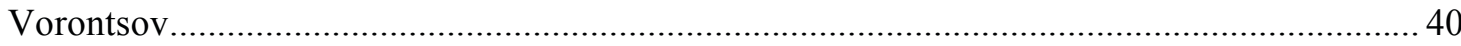

Chapter 3: The Caucasus Theatre and the Battle of Dargo............................................. 45

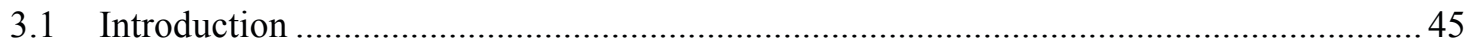

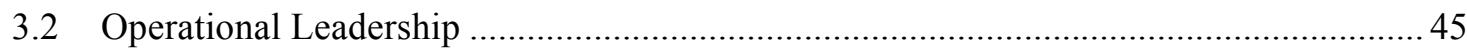

3.3 Lack of General Staff and the Tactical Implications ................................................... 49

3.4 The Tactical Impact of Poor Officer Education ........................................................... 53

3.5 Field Training and Other Habits as they Affected Competency .................................. 58

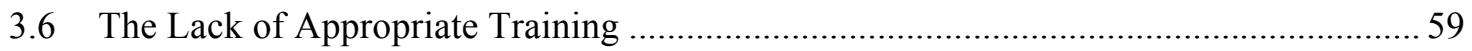


3.7 The Strict Adherence to Napoleonic Doctrine

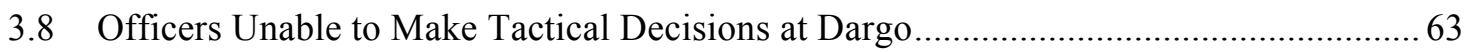

3.9 The Impacts of Regulation on Troop Movements and Formations................................. 67

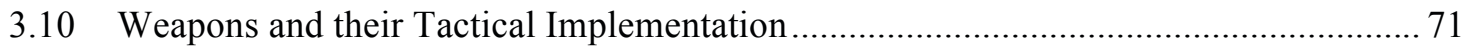

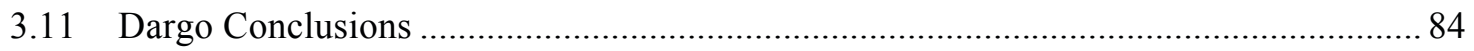

Chapter 4: Central Asia and the effective application of Napoleonic tactics............ 87

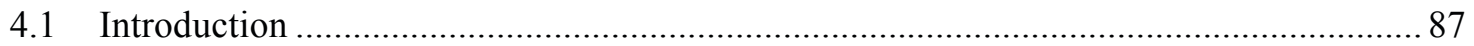

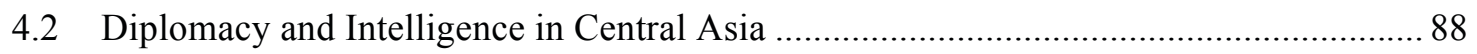

4.3 Overcoming Logistics and Nature in Central Asia...................................................... 90

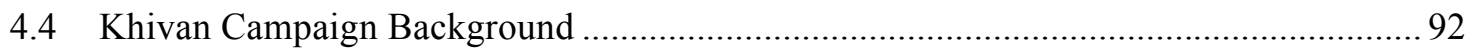

4.5 The Effective Application of Napoleonic Scale Forces and Logistics in Khiva .............. 94

4.6 The Effective Application of Napoleonic Firepower Against the Khivans .................... 97

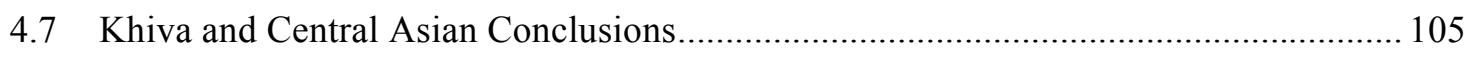

Chapter 5: Conclusion ...................................................................................................... 106

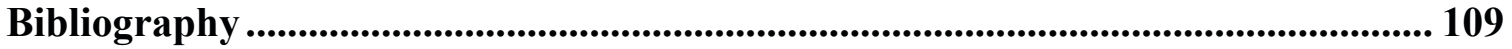




\section{Chapter 1: Introduction}

Russian statehood during the nineteenth century relied heavily on its ability to cast military power. The lines of the Russian nation-state were drawn in no small part by its military in the late eighteenth and nineteenth centuries, a common theme in Europe during those times. Those states that were able to master the projection of military force granted themselves a degree of longevity and vitality. Many nations have nineteenth century military histories that established their power for years afterward. It was in the beginning of this century that Europe saw for the first time continent-wide conflicts between modern nation-states, the results of which would shape its history and create lasting traditions and philosophies. During the Napoleonic Wars the nation-states of Europe crafted military patterns that would carry them into modernity. The Royal Navy of Britain established a primacy that carried through to the Cold War. The principalities that would eventually make up Germany began to formalize the military systems that enabled that state to so rapidly become a global power. France, even after defeat, continued to carry military traditions learned under Napoleon, and would continue to resent the European powers which established themselves in the vacuum of a European French empire. All of these powers would dramatically increase their military presences within their colonial spheres of influence, competing with one another to seize as much territory as quickly as possible. Russia is no exception, and used force to expand its empire and control a vast quantity of land stretching the farthest edge of Asia to central Europe.

Russia would add vast amounts of land to its empire in the nineteenth century through military conquest. In the Caucasus, the Russian military drove as far south as 
geopolitics allowed, brushing up against the powerful Ottomans and Persians. In Central Asia, Russia toppled khanates, stopping only when the British ended their push north from India before Afghanistan. Russia was fully able to compete with the great powers of the era in the games of colonialism, wielding military power across large tracts of Eurasia. European powers accepted Russian strength thanks to the reputation of its military. It is interesting to note then, that in the mountains of the Caucasus, a small group of tribal peoples fought the Russian advance into stalemate for nearly 60 years. The Russian approach to warfare in the Caucasus was wholly unable to deliver an expedient or thorough victory. The Caucasus War became an ongoing conflict, chewing up men and materiel while Russia simultaneously pursued other political and colonial machinations and indeed other significant wars.

If the Russians were unable to bring the Caucasus War to a rapid and decisive end, they proved more than capable of quickly subjugating a large portion of Central Asia, a much larger land mass with a more complex set of geopolitical circumstances. Why were the Russians so able to subdue and seize a multitude of tribes and khanates in Central Asia, when a comparatively small and singular group of mountaineers were able to stop Russian advances in the Caucasus Mountains? It is important for any understanding of Russian military history to examine why the same Russian military system was so unable to deal with one conflict, but so able to deal with another separated by less than a decade in the nineteenth century. In the Caucasus, the Russian military would encounter a type of combat for which they were thoroughly unprepared. This was despite the fact that the established Russian military systems and traditions had proven themselves capable of aiding in the dismantling of what was then considered the most 
powerful military on earth. The tactics and systems that allowed the Russians to defeat Napoleon failed utterly in broken terrain occupied by a small but determined and adaptable foe in the Caucasus Mountains. The fighting there would go on for decades, ending only when geopolitical circumstances enabled a victory. This same system, which had so struggled in the Caucasus, was taken quickly to Central Asia, where it once again found some relevance in suitable circumstances against an enemy that played to Russian strengths.

This work examines the Caucasus War and the conquest of Central Asia from a military-tactical perspective. It shows that the Russian military system of the nineteenth century was constructed and grounded within a European-specific Napoleonic version of warfare that applied very poorly in the Caucasus, though very well in Central Asia. I argue that the Russian military system in place in the nineteenth century was one of stagnation, and allowed for the continued adherence to outdated theory and rejected the realities of modern combat. This was particularly the case in geographical regions that did not conform to models of combat that complied with Napoleonic tactics, strategy and norms.

It will become clear that the Russian military was an institution hampered by a seemingly inherent conservatism and a lack of nuanced and adaptable thought in the early nineteenth century. The policies in place relied too heavily on a model of warfare that quickly grew outdated, and the overtly conservative mindset created from previous success would hamper Russian military thought for much of the century. This led to ignorance in the Russian military system surrounding the prevalent and ongoing threats that system was facing in any unconventional setting. Napoleonic philosophies and love 
for regulation at the highest levels of command did not allow for the development of progressive military thinking, which in turn had negative effects on the whole of the military system. An officer corps that refused to apply predictive intelligence in terms of where they would be significantly engaged failed completely to train their men to be good at anything except parade ground movements perhaps suitable on an 1812 European battlefield, but completely inappropriate for broken terrain and a new type of enemy. These failings would mean the repeated application of inappropriate strategy and tactics in the Caucasus, while contemporary nations, such at the British in India, ${ }^{1}$ were rapidly adapting to unconventional warfare.

The Russian ability to defeat the French Grande Armée engrained into the minds of the Russian officers present the value of the tactics and strategy employed therein. For decades afterwards, despite numerous military studies, they did not see the need to deviate from what they felt were tried and true methodologies. After all, what enemy could ever pose as much danger as the one who had fought all the way to Moscow, after conquering much of Europe? At the highest levels, the Russians relived in their minds, on maps, and on exercise fields, the greatest conflict the world had ever seen against a European enemy who fought on the flat plains of the European continent with musket infantry, sword bearing cavalry, and quantities of artillery.

It would be unfair to state that throughout the Caucasus War there were no efforts at reform or change. While the fighting within the theater itself did not inspire great reformist attitudes, the loss of the Crimean War did lead to introspective thought by some military figures. Russia had considered itself on an even footing with European powers,

\footnotetext{
${ }^{1}$ Kaushik Roy, The Army in British India: From Colonial Warfare to Total War, 1857-1947 (London: Bloomsbury Academic, 2013), 40.
} 
having concentrated much of its military energy in studying and training how to beat European great powers. The loss of a campaign on its own soil against European enemies had a significant impact on the Tsarist military psyche, and likely played a part in granting the political willpower which was needed to finalize the Caucasus War. The war inspired sweeping changes within Russian society, and was a contributing factor to the abolishment of serfdom within the Russian Empire, but the reader will see that it inspired little tactical or operational change on the ground. The British, having suffered as a result of some of their own more antiquated military policies, also introduced societal change. These changes had a direct impact on its military practices, specifically ending the sale of military commissions, which were seen as partially responsible for several episodes of military disaster during the Crimean War. ${ }^{2}$

The enemy in the Caucasus would not conform to any model that Russians had ever experienced, and in fact were an enemy in a setting that would have required a dramatically different force than the nineteenth century Russian army for a successful conquest. The inhabitants of the Caucasus were unfamiliar with Napoleonic warfare, and for good reason. Such an experience would have proven to be of little use to them, and the warriors of the region instead practiced warfare suited to their terrain. Relying heavily on traditional methods but also incorporating modern firearms technology, it will become evident that the mountaineers practiced a system of warfare suited to the region. Tsarist officers often spoke of the apparently natural combat abilities of their mountaineer foes. A Russian force that was light, moved quickly and efficiently, where ingenuity and creativity was rewarded or at least accepted, would certainly have fared better. The

\footnotetext{
2 Albert V. Tucker, "Army and Society in England 1870-1900: A Reassessment of the Cardwell Reforms," Journal of British Studies 2 (1963): 111.
} 
reader will see that a force that could have least rendered some kind of effective return fire, even if doing nothing else effectively, very likely would have experienced more tactical success during battle. A lack of ability to learn, even after the Caucasus War and Crimean War, did not have as great an impact on the Central Asian campaigns where the terrain types and adversaries the Russians encountered conformed more to what they were drilled to deal with, and required no great reform initiative. Russian expertise in Napoleonic warfare greatly aided their success in Central Asia, as the topography and enemy there allowed for the full implementation of the system, which the Russians had been using, for better or for worse, since Napoleon.

\subsection{Structure}

The initial section of this work will offer a background on Russian conquest, and present several theories to improve our understanding of the conquest of the Caucasus and Central Asia in the nineteenth century. Built into this is a chronology of events designed to provide context. A section establishing the theory and conduct of Napoleonic tactics is then provided, so that the reader will have a better understanding of how they shaped Russian military thought and action. Following this a study of Russian military theory and thought as it affected the whole of the Russian military system will be presented. The sections deal with: operational leadership; the lack of a general staff body; problems within the military education system; field training; and finally weapons and other arms. Within each of these sections, I analyze evidence, based on primary sources, for the negative tactical implications of these issues. This is done through an examination of contemporary accounts of the Battle of Dargo in 1845, which was meant 
to end the threat of Shamil of Dagestan, the commander of the allied mountaineers who opposed Russian rule in the region. Subsequently, an examination of the second major Russian operation to subdue Khiva in Central Asia, in 1873 is presented, based largely on primary accounts. This examination will show that the Russians encountered there a form of warfare at which they already excelled.

\subsection{Literature Review}

The initial phases of my research into the topic of Russian nineteenth century expansionism led me to a number of sources that indicated that a military factor was paramount in both Russian expansionist successes and failures. Further research into this specific topic led to the creation of this work, and as such the works discussed here pertain primarily to military events or circumstances.

The majority of the sources encountered did not provide the needed level of tactical analysis to effectively determine the impact of Russian military methods in nineteenth century theaters, and often only discuss military issues within a greater political narrative. Sources which focus entirely on Russian military issues paint a picture of a force unable to develop and adapt during the nineteenth century, and yet these same sources do not significantly offer that these issues may have had a negative impact on the Russian army's combat performance. In works that focus on the combat narratives, analysis of the system behind the Russian military is taken for granted.

With the limitations of the current body of literature in mind, the aim of this work is to further analysis of the impact of the established Russian military system on its combat capabilities in two comparative case studies. The reader will see that while the 
existing body of literature covers a large segment of analysis, this work incorporates discussion of the Russian military system and the tactical narrative, and applies that discussion to a primary evidence based comparative assessment. As will be further demonstrated by a review of the relevant sources, this approach appears to be unique.

Within the body of literature that deals with both the Caucasus and Central Asian conquests, the only significant debate is regarding the impact of Islam on Russian attempts to integrate the Caucasus into its holdings. There exists little debate regarding a comparative analysis on effectiveness of the tactics used by the Russians in the Central Asian or Caucasus wars. Indeed, none of the examined works contain a strong comparative element, and none explicitly identify the failure or success of the Russian military system as a singularly important factor within a conflict, despite providing ample evidence for this point.

A good example of a work which identifies a singular factor, namely the impact of terrain on its inhabitants, as being primarily responsible for the longevity of the Caucasus War is "Myths and Mysticism: A Longitudinal Perspective on Islam and Conflict in the North Caucasus," by Michael Reynolds. Reynolds' work is also an excellent example of a piece which debates the impact of Islam in Caucasian resistance, arguing that much of the historical analysis of resistance in the North Caucasus has pointed to Islam as a primary factor and that this emphasis is exaggerated. Major works on this subject that take an opposing view include Gammer's Muslim Resistance to the 
Tsar, discussed below, but there are a multitude of works which credit Islam as a major factor in the ability of the people of the Caucasus to resist Russian military influence. ${ }^{3}$

Reynolds uses a simple, longitudinal analysis of the history of the region, supplying alternative factors that may have enabled resistance. He states that the topography of the region did not facilitate the command of large invading armies and that the "rugged and fierce nature of the region's inhabitants" ensured that the Muslim forces from the south would never exert full control over the area. Reynolds shows that during the period from these initial Arab invasions all the way up to the Russians incursions into the area factors such as, "the difficult terrain, the mountaineers' pugnacity, and the lack of [local] central government" ${ }^{55}$ made conquest a costly initiative for numerous foreign militaries. Reynolds' examples point to Islam as being a factor in resistance, but of secondary importance to factors such as "the nature of mountaineer society, which, in part due to the unique geography of the North Caucasus, has remained resistant to centralized rule of any sort."

Reynolds' approach proved helpful in the creation of this work in that it allowed for an appreciation of alternate interpretations of the established histories such as Gammer's, Broxup's and Murphy's. My own evidence also pointed away from religion as a primary motivating factor in resistance. Additionally, Reynolds' emphasis on the

\footnotetext{
3 There are a significant number of works that point to Islam as a primary factor in the Caucasus' resistance to Russian rule, many nuanced like Gammer's. Several works consulted herein that take this viewpoint are Marie Broxup's The North Caucasus' Barrier: The Russian Advance to Towards the Muslim World (London: Hurst, 1992), and Anna Zelkina's In Quest for God and Freedom: Sufi Responses to the Russian Advance in the North Caucasus (New York: NYU Press, 2000).

${ }^{4}$ Michael Reynolds, "Myths and Mysticism: A Longitudinal Perspective on Islam and Conflict in the North Caucasus," Middle Eastern Studies 41, no. 1 (2005): 34.

5 Ibid., 35.

6 Ibid., 48.
} 
terrain and its impact it had on its inhabitants pointed towards the need for a similar analysis of the effect on the Russian military.

Works such as Muslim Resistance to the Tsar: Shamil and the Conquest of Chechnia and Dagestan by Moshe Gammer represent the other side of the debate surrounding the impact of Islam on the Caucasus war. Gammer's study was important for the creation of this work in its focus on Islam, the mountaineers, and key mountaineer players as the most important factors that enabled resistance to Russian conquest. Gammer's work is centered on Shamil, an Islamic leader who many scholars see as uniting a previously fragmented resistance movement during the Caucasian Wars (roughly late $18^{\text {th }}$ century to 1859 ). Rather than seeing Islam itself as the primary factor in resistance, Gammer identifies Shamil and his ability to create unity behind a shared Islamic faith as being a major reason behind the longevity of the mountaineers' resistance to Russian rule. Gammer's nuanced Islam-based argument does represent an alternative viewpoint to those held by scholars such as Reynolds, whose arguments lend more weight to alternative factors.

As Gammer's focus is on Shamil, much of the work is concerned with analysis of events in which he played a part, but he opens with a description of events before that Dagestani leader's rise to prominence. Gammer concludes that for North Caucasian peoples Islam was an important feature of resistance even before Shamil. ${ }^{7}$ However he also observes that other characteristics of these people, separate from Islam, such as their "extreme vigilance over their freedom and the strong rejection of any authority external

\footnotetext{
7 Moshe Gammer, Muslim Resistance to the Tsar: Shamil and the Conquest of Chechnia and Dagestan (London: Frank Cass, 1994), 21.
} 
to the tribe or clan" also had an impact on their resistance. Gammer also discusses the state of the Russians, calling them "the mountaineers' opposite in almost every conceivable way." ${ }^{\circ}$ He states that the former were slow, reliant on logistical support and essentially not cut out for war in the mountains and forests. Portions of the work read like a comedy of errors regarding the Russians, as they suffered defeat at the hands of a smaller foe while only making periodic and often costly gains. Here again, even within a work more outwardly focused on a singular actor, we see the recurring themes of the unsuitability of the Russian military system in the Caucasus.

Gammer's arguments are well-founded, and Shamil was certainly a key factor of mountaineer resistance. However, despite offering narrative that discussed the inability of the Russian military to cope with the Caucasus, Gammer offers only small portions of analysis as to why that might have been the case. Seeing this analytic gap further justified the subject of this work, and the close focus on the Russian military factor rather than on unique circumstances within the local populations of the Caucasus.

John F. Baddeley, author of The Russian Conquest of the Caucasus, ${ }^{10}$ does not deal with questions of Islam's impact on the hostilities in the region. Rather the work is largely a narrative history of a type one would expect from a Victorian historian. He endeavors to record the past, the history of the Caucasian War, from an unbiased viewpoint by relying heavily on hard documentation, including some of the evidence referenced within this work's analytic portions. As such the work is not analytical, and Baddeley does not overtly push to theorize the events. As a background study on the

\footnotetext{
8 Ibid.

9 Ibid., 23.

10 John F. Baddeley, The Russian Conquest of the Caucasus (New York: 1969, Russell \& Russell).
} 
subject of the Caucasus War, the work remains heavily cited by modern scholarship on the region and as such seems to be taken as largely valid and well researched. Gammer calls the work "the best study" ${ }^{11}$ available. Despite Baddeley's work being concerned only with narrative, recurring themes of Russian unpreparedness for combat in the region are again present. As the work is comprised almost entirely of primary accounts, it lends itself well to those hoping to draw their own conclusions about the state of the Russian military in the Caucasus War. No other western scholarship disputes versions of any of the events contained within Baddeley's work, much of which confirms the evidence within The Russian Conquest of the Caucasus.

One such work is The Russian Army Under Nicholas I: 1825-1855 by John Shelton Curtiss. This work deals with the structure and methods of the specific generation of the Tsarist military, which fought most of the Caucasus War. Of particular pertinence to the Caucasian theatre is a chapter that deals with the training, equipment and methods of the Tsarist infantry. This group is important as it was forced by geography to do most relevant fighting in the region. In addition to this chapter there is another within Curtiss' work that deals with the Caucasus War itself, applying his own analysis of the Russian military to the events of that conflict. Curtiss describes a force that appears to have been extremely ill-prepared for the particularities of the Caucasian environment. He returns frequently to themes wherein Russian officers felt that antiquated Russian military thinking was "sanctified by success."12 He pays particular attention to weapons, and goes to great lengths providing evidence to show that the

\footnotetext{
${ }^{11}$ Gammer, Muslim Resistance to the Tsar, xv.

${ }^{12}$ John Shelton Curtiss, The Russian Army Under Nicholas I: 1825-1855 (Durham, N.C.: Duke University Press, 1965), 115.
} 
Russian soldier received only very little of even the most rudimentary marksmanship training for the effective employment of his often unserviceable muzzle loading musket. ${ }^{13}$ The analysis within Curtiss' work largely concurs with that of scholars such as Gammer in that the Russians were not prepared for war in the Caucasus. The difference in Curtiss' work is that it provides an enhanced military-analytic portion, choosing to focus on the large-scale Russian military during the nineteenth century. Curtiss' work provided an excellent analytic platform from which to delve down to a level of greater detail focused on specific events in the Caucasus and Central Asia, with a decided military focus.

As is hopefully evident, much of the major scholarship dealing with the Caucasus War contains themes of Russian unpreparedness. Even when authors attempt to relay specific arguments outside of the purely military aspects of the conflict, this theme seems to be inescapable. Clearly, this is an issue of vital importance to an understanding of that war. This work will seek to rectify this apparent gap in the scholarship of the conflict by isolating the military factor and assessing primary accounts of events on a baseline of study on the Russian military system.

The theme of Russian military unpreparedness is lacking almost completely from works dealing with the Russian conquest of Central Asia. Instead, these works imply the existence of a Russian military system that, while not perfect, was more suited to the type of combat it would encounter there. This work will take analysis of a Central Asian campaign further, examining how this more suitable Russian military system came to be,

${ }^{13}$ Curtiss, The Russian Army, 120-130. 
and the reasons behind the comparative success of Central Asian campaigns over those within the Caucasus War.

"Russian-Soviet Unconventional Wars in the Caucasus, Central Asia, and Afghanistan," by Robert F. Baumann, deals with the Central Asian conquest as a whole, but does so with a significant military focus. Baumann is also the only scholar encountered during the research of this work who alludes to a positive impact in Central Asia from the Caucasus experience. He cites the importance of the unconventional experience gained by officers who served in the Caucasus moving their skills to Central Asia. ${ }^{14}$ Baumann notes that while the relationship of Russia and the khanates of Central Asia had always been marked by periodic violence, it was late in the nineteenth century, after the Crimean War, that the conquest began in earnest. After failing to force concessions from the khanates through diplomatic means, the actions of a few ambitious military commanders forced a re-examination of the question of the subjugation of Central Asia by Russian political powers. Baumann states that in subsequent military campaigns, Russian firepower was far more than a match for the armies of khanates, which tried unsuccessfully to imitate a European military structure. ${ }^{15}$ Baumann does not discount completely this enemy, whom he states could be very dangerous to the Russians if they didn't adhere strictly to formation protocol when making logistical or operational movements across deserts in the region. ${ }^{16}$ Much of the discussion of issues that hampered Russian progress in the region is concerned with movement and logistics, but Baumann

\footnotetext{
14 Robert F. Baumann, "Russian-Soviet Unconventional Wars in the Caucasus, Central Asia, and Afghanistan," Leavenworth Papers: Combat Studies Institute, US Army Command and General Staff College 20 (1993): 49.

15 Ibid., 59.

16 Ibid., 60.
} 
implicitly discusses that in Central Asia, unimpeded by mountainous terrain, the Russians were able to employ the vast supply trains of Napoleonic doctrine ${ }^{17}$ with success. ${ }^{18}$ Baumann's work is a particularly useful source in that he does apply some sound military analysis to events. Unlike the majority of scholars who provide only a narrative of military events, Baumann applies a tactical or operational analysis, making some judgment as to the effectiveness of specific military actions. Many scholars omit this particular facet of analysis, focusing on relaying the military narrative, and analyzing military elements either only briefly or not at all, choosing instead to comment on political or social factors.

Baumann's work provided an excellent example of analysis of both the Caucasus and Central Asian conflicts from a military perspective. Consulting this source made it evident that this type of analysis was readily applied to the topic, and that there was room for a more detailed, event-based analytic approach. Bauman also does not discuss any comparative elements, nor does he assess events based on the evolution of the Russian military system at the time, both things which will be done within this work.

Alexander Marshall, in The Russian General Staff and Asia: 1860-1917, discusses the development of top tier military thinking as it pertained to Asian theaters of war. The work provides important information on everything from the establishment of Asian

17 To fulfill the need for large quantities of ammunition, animals, and ordinance as required by Napoleonic doctrine, large supply trains were a necessity. These were so significant that they in turn required additional logistics support for the animals and people involved in transporting the equipment of military forces. A detailed explanation of Napoleonic doctrine will be given later within this work.

${ }^{18}$ Baumann, "Russian-Soviet Unconventional Wars," 60. 
literature military libraries designed to aid in the strategic process,${ }^{19}$ to the specific strategic challenges of the Caucasus, and Central Asia. What is particularly interesting is the amount of discussion among Russian officers of the General Staff regarding strategic questions in Central Asia. This does seem to differ from the approach taken within the Caucasus, where very little was undertaken in terms of studies of terrain or the inhabitants prior to launching military actions there. In a chapter devoted to Central Asia, Marshall breaks down numerous strategic and geographical studies undertaken by these men, ${ }^{20}$ analyzes the observations they made of potential enemies ${ }^{21}$ and notes their high levels of contribution to the body of Russian military professional literature..$^{22}$ On their own, these observations do not say anything particularly novel about the Russian military system's interactions with Central Asia. However in comparison to Marshall's discussion of the Caucasus theatre, these observations do indeed appear to be of note. In the Caucasus, officers were more often than not concerned with the machinations of foreign powers to incite revolt or invasion in the region, ${ }^{23}$ rather than focusing on the enemy that already existed in front of their eyes and soldiers.

Marshall's work does indicate some developments from the Caucasus to Central Asia within the strategic planning abilities of the Russian staff. The fact that studies focused on the terrain and inhabitants were undertaken at all shows that some officers felt there would be a need for a more thorough approach in Central Asia. What Marshall does not show is how little impact these studies had on the tactical situation on the

${ }^{19}$ Alexander Marshall, The Russian General Staff and Asia: 1860-1917, (New York: Routledge, 2006), 17.

${ }^{20}$ Ibid., 131.

${ }^{21}$ Ibid., 142.

22 Ibid.

${ }^{23}$ Ibid., 109. 
ground in that theater. The Russian military fought there largely as it had in the Caucasus. Of course, high-level strategic studies do not necessarily cause change in tactical training or operational planning, and Marshall's evidence taken in combination with that provided in other sources shows this to have been the case in Central Asia. Marshall's work once again showed the need for a direct military comparison between the two theatres to determine the impact or lack thereof of this inability to change or adapt by the Russian military on the ground.

The primary evidence reviewed within this work points to similar themes. Officers writing of their time in the Caucasus typically discuss events in a very matter of fact way, however it is easy to read between the lines and see that these men largely understood that their combat methods and general approach to warfare in that theater was imperfect. This sentiment is present in the writings of men at the highest echelons of command, down to junior officers, and will be presented within this work in a later chapter. Primary source evidence composed by men who fought in Central Asian campaigns is notably devoid of these sentiments, and a recurring theme within these writings is that of the columns versus the natural elements, and in fact little mention is made of their Central Asian adversaries.

What none of the research reviewed within this work does is make an attempt to explain why, from a comparative perspective, the Russian military system in place in the nineteenth century did so much better in Central Asia than it fared in the Caucasus. This work will provide that linkage, utilizing some of the existing themes within the scholarship to show why the Russian military was so ill-prepared for engagement in the Caucasus, but so much better prepared for engagement in Central Asia. 


\subsection{Historical Background}

The following section will outline a chronology of events for the eventual conquest of the Caucasus and Central Asia to establish a contextual and narrative background for a detailed analysis of the Russian military's performance. The Russians had long had encounters with the peoples of the Caucasian ranges, ${ }^{24}$ but most scholars put the start date of the so-called Caucasian War somewhere around the start of the nineteenth century. The year 1816 seems a more precise estimate, as this marks the appointment of General Aleksei Petrovich Ermolov to the position of governor and chief administrator of the Caucasus and Georgia. Ermolov was the first Russian to enact a policy of conquest in the region rather than to simply make attempts to administer it.

The direct road to the "need" to control the Caucasus region came as a result of threats to the kingdom of Georgia, which had long been confronted by powerful aggressors to the south. In 1800, King George XII took the Georgian throne. After having received threating letters from the Shah of Persia, Feth Ali, King George was encouraged by a Russian envoy to refuse compliance with any Persian terms and to seek protection from the Russian empire. Tsar Paul I learned of these circumstances, and ordered a Russian General in the region to prepare a force and cross the Caucasus Mountains as a display of Russia's willingness to protect Georgia. ${ }^{25}$ Persian and allied armies began to make strategic moves in the region, and by December of 1800 a dying King George cast any hope of his nation surviving into Russian hands, offering up the Georgian crown to Paul I. Ten days after King George's death, Paul I published a manifesto of compliance and in effect became the direct ruler of the Kingdom of Georgia.

\footnotetext{
${ }^{24}$ Baddeley, The Russian Conquest of the Caucasus, 1-22.
}

25 Ibid., 60. 
Russian officials took firm control of the state after erasing the threat posed by the surviving relatives of the former King, who had attempted to create conditions favorable to the resurrection of the Georgian dynasty. ${ }^{26}$

In 1816 General A. P. Ermolov was dispatched to the region to solidify Russia's hold on the areas between southern Russia proper and the newly acquired Kingdom of Georgia, the North Caucasus. Ermolov's strategic system essentially revolved around a line of fortifications in the North Caucasus, the idea being that they would serve as a starting point for raids to the south. Garrison troops are typically of poorer quality than those taking part in an operation due to simply being bored and having a routine aimed not at increasing combat effectiveness but maintenance and other chores. ${ }^{27}$ This made many of these forts, built in haste, prime targets for insurgent raids. Within decades of low level fighting, an example of one such raid is one that occurred on the night of 20 July 1825. At this point the Russians were very much following the system attributed to Ermolov, fortifying as much as they could and launching punitive raids against populations near the forts if they dared to resist. Insurgents stormed Amir Hajji Yurt, killing 98 of the 181 defenders and taking 13 prisoners, a disastrous result for the Russians. ${ }^{28}$ The fort at Amir Hajji Yurt was under the regional command of General Grekov, who pursued the Ermolov system with devotion, and a noted cruelty. ${ }^{29}$ The fort was simply chosen as a target by a large group of local insurgents and attacked, a scenario that repeated itself throughout the Ermolov style of warfare. Ermolov responded

\footnotetext{
${ }^{26}$ Baddeley The Russian Conquest of the Caucasus, 65.

${ }^{27}$ Julius Friedrich von Hille, The American Revolution, Garrison Life in French Canada and New York: Journal of an Officer in the Prinz Friedrich Regiment, eds. Helga Doblin and Mary C. Lynn (Westport CT: Greenwood Publishing Group, 1993), xiv. ${ }^{28}$ Gammer, Muslim Resistance to the Tsar, 36.

${ }^{29}$ Baddeley, The Russian Conquest of the Caucasus, 148.
} 
by launching a series of punitive raids, which ran back and forth over the Caucasus, burning villages and killing untold numbers of locals. ${ }^{30}$ This entire event and indeed the system that manifested it represented a thorough defeat for the Russians. Not only did they suffer significant casualties at Amir Hajji Yurt, Russian actions served to increase anti-Russian sentiment within the local populations.

To make matters worse for the Russians, a new leader had begun to unite fractured tribes in the mountains. Shamil of Dagestan was the charismatic leader of the Murids, an Islamic-based Sufi religious movement that would eventually make up much of the mountaineers' rebellion. It is certainly true that Shamil had an impact on the conflict- had the mountaineers remained divided into kin groups, it is possible the Russian practice of fort building may have been more effective, as the mountaineers would not have been able to gather enough strength to offer any kind of significant attack against these installations.

By the mid nineteenth century, some notable Russian offensives were beginning to take place, as the need to directly target Shamil's forces became apparent. An expedition undertaken by General Grabbe in 1839 was meant to secure the destruction of Akhulgo, where Shamil was positioned at that time. ${ }^{31}$ Grabbe marched his 8000 men through heavily mountainous terrain, and was forced, due a lack of ability to withdraw, to attack Shamil's position earlier than anticipated. Shamil fought a tactical withdrawal to Akhulgo, where Grabbe attempted to make a siege, but was lacking almost everything

\footnotetext{
30 Gammer, Muslim Resistance to the Tsar, 37.

31 Baumann, "Russian-Soviet Unconventional Wars," 12.
} 
needed for such activities. ${ }^{32}$ Grabbe was forced to withdraw with 3000 or just under half of his force. ${ }^{33}$

Shamil emerged from the battle even more influential and bold than before, and the Russian inability to hold the ground they had taken at Akhulgo only bolstered his prestige. ${ }^{34}$ Shamil would launch several spectacular offensives, and managed to inflict casualties in the thousands on the Russians, and the 1840s are seen as the low point for the Russians during the conflict. ${ }^{35}$

Expeditions like the one undertaken by Grabbe, and the expedition to Dargo featured within this work, became the norm for the Russians seeking a way to end this conflict. By the early 1850s Prince M. S. Vorontsov, who then had command of the theatre, realized he could not deal Shamil's forces a lethal blow with his current disposition. He nonetheless contented himself in letting events play out as they had in the past. ${ }^{36}$ In 1852 General Prince Aleksandr Bariatinskii became the commander of the left flank, and set about devastating Chechnya with little real strategic impact on the conflict as a whole. ${ }^{37}$

This expensive methodology of raiding without attempting to actually wrest control of the region away from the mountaineers would be interrupted by the outbreak of the Crimean War in 1853. This was the war Russia had been preparing for, a war against a European rival. Interestingly, despite the fact that the war drew almost of all Russia's attention, Shamil, apparently occupied by internal political issues at the time, failed to

32 Baumann, “Russian-Soviet Unconventional Wars," 15-16.

33 Ibid., 17.

${ }^{34}$ Ibid., 17.

35 Ibid., 20.

${ }^{36}$ Baddeley, The Russian Conquest of the Caucasus, 487.

37 Ibid., 444. 
capitalize in the Caucasus while it was ongoing. ${ }^{38}$ Equally interesting is that Russia did not send, in any significant quantity, the hardened Caucasus Army troops to the Crimea. ${ }^{39}$ As the war concluded, the Russians were able to return to the Caucasus with fresh desire to end that conflict. Prince A. I. Bariatinskii was made commander in chief of the region, and he brought General D. A. Miliutin as his chief of staff. They, for the first time, formulated a grand strategy for the defeat of Shamil. ${ }^{40}$ Baddeley states that these men themselves did not imagine how successful their plans would be, and that they were very fortunate in terms of timing. Shamil had begun to lose control of some elements of his forces, ${ }^{41}$ and this dis-unified force appears to have been an easier match for the Russians, who would make no real significant tactical or strategic changes to defeat Shamil in 1859.

The generals who had put an end to that conflict saw the Caucasus "as a secure base for expansion into Central Asia." 42 As the Caucasus War came to a close, the officers involved there encouraged their more aggressive counterparts at the heights of the Russian administration, "flooding Petersburg with proposals on Central Asian policy." ${ }^{23}$ This aggression emanating from the tactical level did not fall on deaf ears at the strategic centers of the empire. Indeed, for the reasons previously mentioned regarding the end of the Caucasus War and the Crimean defeat, and "the prospect of sizable, inexpensive gains in Central Asia tempted a regime anxious to restore its shaken

\footnotetext{
38 Baddeley, The Russian Conquest of the Caucasus, 447.

39 Ibid., 450.

40 Ibid., 458.

41 Ibid.

42 David MacKenzie, The Lion of Tashkent: The Career of General M.G. Cherniaev (USA: University of Georgia Press, 1974), 27.

43 Ibid., 29.
} 
prestige and prove Russia's equality with the western powers."44 David MacKenzie in his The Lion of Tashkent also lists other, seemingly pragmatic, reasons behind the sudden Russian desire to push south. Cotton features among them, and Mackenzie states that at that time the world was undergoing a cotton shortage, thanks largely to the American Civil War, and "prospects of abundant cotton from Turkestan and Bukhara attracted Russian manufactures hard pressed to meet burgeoning domestic demand."45

The khanates would fall one after another, seldom being able to offer a serious military challenge to Russian campaigns. Bukhara would fall in 1868, followed by Khiva in 1873 , and finally Kokand in 1875. The Khivan Campaign of 1873, the subject of a detailed analysis later in this work, was a typical episode within the greater conquest of the region. Holding these areas and ensuring that Central Asian states remained internally peaceable would prove to be the more challenging prospect, as revolts began to break out in 1875 causing the Russians to exercise their conventional military muscle. The Russian response to these uprisings would lead to the more complete conquest of Kokand. ${ }^{46}$ Another revolt in 1879 , this time at the hands of Turkomen in the Teke oasis of Transcaspia, required a similar exercise in conventional warfare on the part of the Russians. Here the Russians were handed a significant defeat, when General Lomakin, utilizing poor counter-fortress warfare tactics, attacked a Turkoman stronghold with an ill-prepared Russian force. His defeat led then Minister of War General Miliutin to quickly organize a second attack, this time in the hands of General M. D. Skobelev, who had recently proven himself in the rebellion in Kokand. Skobelev exercised his full

\footnotetext{
${ }^{44}$ MacKenzie, The Lion of Tashkent, 30.

45 Ibid.

46 Baumann, "Russian-Soviet Unconventional Wars," 68.
} 
tactical and preparatory abilities, and seized the Turkoman stronghold of Geok Tepe inflicting hugely disproportionate casualties on his opponents within. ${ }^{47}$ Baumann in "Russian-Soviet Unconventional Wars" states that the capture of Geok Tepe by General Skobelev "extinguished the last effective resistance to imperial rule Central Asia." 48 The Caucasus and Central Asia represent two very different theatres of war. Despite this fact, the Russians pursued combat on the ground much the same way in both regions, gaining very different victories. In the Caucasus, a united and determined enemy exploited the inappropriateness of the Russian system of warfare in that region, causing the conflict to drag out for half a century. In Central Asia, despite applying the same systems, the Russians were able to quickly subjugate and dismantle local powers, using their military might and a system that proved to be ideal for combat in that region.

47 Baumann, "Russian-Soviet Unconventional Wars," 74.

48 Ibid. 


\section{Chapter 2: Russian Military Theory, Strategy, and Politics and Their Impact on Military Performance}

\subsection{Introduction}

The fundamental nature of the Russian military system, creating a military uniquely ill-suited to combat in the Caucasian theater of war, allowed such a long and costly campaign there. This chapter explores the state of Russian military thought during the nineteenth century prior to and during both the Caucasus War and the Central Asian campaigns, allowing for an examination of how these theories and practices affected combat. The thought and practices discussed within this chapter had direct impacts on the conduct of war in both theaters under examination.

Bruce Menning in Bayonets Before Bullets calls the army leading up the Crimean War "huge in size, ponderous in movement, unimaginative in leadership, and bound to an outmoded socioeconomic system. ${ }^{\prime 49}$ This is an apt description of the Russian military as it entered into and conducted the Caucasus War. Principles employed during the Napoleonic war, strictly adhered to by the Russian military, caused serious issues within the areas of operational leadership, the general staff, military education, field training, and weapons and other arms. The strategic, tactical, and academic stagnation, which so plagued the Russian military as a whole, had serious consequences in the Caucasus War. It created leaders ill-prepared for a battlefield which would reward adaptive tactical practitioners, capable of appropriately using their men and terrain, rather than tactically

\footnotetext{
49 Bruce Menning, Bayonets Before Bullets: The Imperial Russian Army, 1861-1914 (Bloomington: Indiana University Press, 1992), 7.
} 
conservative commanders who attempted to fight as though they were at Austerlitz or Jenna.

This chapter shows how Russian military thought failed to deliver a decisive or quick victory in the Caucasus War. It examines the follies of the military education system and the vehicles of that system in the form of academies, and the accepted tactics, training and procedures of the era up to the Crimean War. Reform attempts in the nineteenth century were numerous, and driven by some of the most influential Russian military thinkers of the era, but in the end, the conservatism of the Russian state and military would render liberal or reformist ideas largely irrelevant on the battlefield. This conservatism likely stems from Russian belief in the infallibility of what had been a successful military system. A number of other factors also contributed to the continuation of these beliefs through decades of unsuccessful warfare. Defeat at Crimea caused only limited reform efforts, though did provide the political impetus that enabled the creation of circumstances to end the Caucasus War.

Training and doctrine form the core of any military force and its action and reaction in combat or operational situations. The Russian military ignored advances in areas at which other nations were rapidly developing, such as asymmetric warfare, technology, and command and control measures. It will also become evident that the Russian military seems to have fostered an ignorance regarding the specific type of conflict in which it was engaged in for most of the nineteenth century. The evidence in Chapter 3, presented through a case study of a significant battle fought within the Caucasus War, shows the Russian military was wholly unsuited for combat in the mountainous terrain of the Caucasus against a skilled unconventional foe. Within the 
Central Asian context a similar approach is used. The evidence from the Central Asian wars points to a much better prepared Russian military, operating in a fashion with which it was comfortable and experienced against a foe that allowed itself to be engaged in a familiar way, unlike their Caucasian counterparts. It will become plain that this was the case because the Central Asian theatre offered ample opportunity for the Russians to employ well rehearsed Napoleonic tactics, while the Caucasus had offered none.

\subsection{Napoleonic Tactics and Doctrine}

The following section explains the basic military tactics utilized during the Napoleonic Wars. "Napoleonic" tactics consist of those developed and used during the wars against Napoleon's forces in the late $18^{\text {th }}$ and early $19^{\text {th }}$ centuries. They were largely the result of available technology - primarily, the muzzle loading musket. With an accurate range of only about 60 yards, these weapons needed to be fired in close proximity to one another and to one's enemy. Ideally, these weapons were fired in a pattern designated by the units within the firing line, so that one group was always firing, another was reloading, and a third was making ready to fire. The effect of this was a continuous rolling volley of firing often referred to as platoon fire, and was a difficult tactic to master. Difficulty in reloading these weapons meant that many nations would in fact forego firing more than one volley prior to charging an opposing line of soldiers, hoping to force a break in that formation. If this was achieved, it was expected that the enemy line would disintegrate and that body of troops would be routed, ensuring a tactical victory within a battle. Thus breaking an enemy line of troops became the focal point for this set of tactics. To do this, flat firm ground and good weather were ideal. 
The firm ground allowed for the maneuvering of heavy artillery pieces, and good weather was needed to allow for the ignition of the dry gunpowder exposed on the flash pan of a musket. $^{50}$

These tactics were not considered limiting at the time, as they were based on available technology. A whole set of complicated formulas and methods was developed to give a commander a host of options based on elements such as weather, terrain, and available troops and resources. In a sense, the tactics were limited in that there were ideal sets of circumstances under which to use them, such as dry weather and flat ground, and less ideal ones, such as broken terrain and rain. One has to keep in mind however that in a battle being fought within Napoleonic convention, if a commander was forced to deal with a negative set of circumstances, so was his enemy.

The infantry, the primary element of force, fought in what is known as close order. This was made up of tightly packed lines of men, turned to face the enemy with as much frontage, or pointed muskets, as possible. This meant that the maximum amount of firepower could be brought to bear, and it also meant that opposing artillery rounds impacting the line would only kill 2 or 3 men before passing completely through the formation. ${ }^{51}$ This was far more preferable to the impact of an artillery ball passing through a thick formation of men who were not formed in a frontage bearing line. Firm flat ground also allowed for the effective tactical movement of infantry and cavalry, and even the slightest elevation gains were considered to be key. ${ }^{52}$ Seizing the high ground in a battle granted the commander extended vantage over the battlefield, and forced the

\footnotetext{
${ }^{50}$ Rory Muir, Tactics and the Experience of Battle in the Age of Napoleon (New Haven: Yale University Press, 2000), 13.

51 Ibid., 70.

52 Ibid., 16.
} 
enemy to attempt to attack uphill, a difficult feat. Additionally, it was typical for Napoleonic infantry to deploy a small screening force of what were known as skirmish troops, whose job it was to fire at enemy officers and other key targets, and to stop enemy skirmishers from doing the same. Artillery, able to kill enemy troops at much greater range than musketry, also maintained an important place in Napoleonic commanders' minds. ${ }^{53}$ Properly sighted and placed artillery could inflict devastating casualties on enemy formations of infantry or cavalry before they became a threat. Strict control of all of these elements was needed to ensure that the infantry advanced under potentially aggressive enemy fire to a range at which they could employ their own muskets, and hopefully charge into the enemy line and cause a retreat. The cavalry could aid in this process by attacking the flanks of an enemy infantry formation, where they could bring no firepower to bear, or by attempting to disable enemy batteries of artillery. The continued adherence to Napoleonic tactics is critical to understanding why the Russians faired poorly in the Caucasus theatre. A devotion to the Napoleonic principles of regulation, uniformity, strict formation protocols and inappropriate weapons represent a few of these key flaws when transferred. Only after the experience of the Crimean War and the end of the Caucasus War did change trickle down to where it might have positive effect.

\footnotetext{
${ }^{53}$ Muir, Tactics and the Experience of Battle, 34.
} 


\subsection{High Level Organizational Issues}

The following section will discuss the upper level issues - strategy, politics, and academic and military theory — which affected the performance of the Russian military in the Caucasus. While it would be difficult to find specific, tactical manifestations of these problems, they influenced military thought and the business of war. Officers fighting in the Caucasus had to work within the theoretical and strategic reality with which they were familiar. That is to say, military theory, strategy and tactics are very much connected. Organizational problems created issues within all of these areas and impacted general command and control capabilities and even military finance.

The Russian military system coming out of the Napoleonic Wars was in some ways an impressive one. After all, this system "produced the armies that forced the French from Moscow and went on to fight at Leipzig and to occupy Paris., ${ }^{, 54}$ Frederick W. Kagan in The Military History of Tsarist Russia states that following the Napoleonic Wars "Europe's conviction [was] that Russia was immensely strong - almost invincible." The importance of the Napoleonic Wars, in terms of their impact on academic, strategic and basic underlying principles and traditions of European military systems, was enormous. Any and all key or significant military philosophies developed in the first half of the nineteenth century have their roots firmly within a Napoleonic context. This included the formation of general staffs to manage the ballooning militaries, which were themselves the direct result of the first true pan-European modern war. ${ }^{55}$ These postNapoleonic War ideas came from thought devoted to preparing for a similar conflict in a

\footnotetext{
54 John Shelton Curtiss, The Russian Army Under Nicholas I: 1825-1855 (Durham, N.C: Duke University Press, 1965), 116.

55 Mayzel Matitahu, "The Formation of the Russian General Staff: 1880-1917, A Social Study," Cahiers du Monde russe et sovietique 16, no. 3 (1975): 298.
} 
similar theater. Kagan describes that legacy as "the most double edged of all, for it concealed the many and important weaknesses from which Russia suffered... and throughout his reign Nicholas I would work within the paradox of Russia's apparent strength and actual weakness."56 This was especially unfortunate; as Kagan points out that while the first 28 years of Nicholas' reign have been called peaceful in that Russia did not engage a major European power in that time, Russian forces were almost constantly engaged in combat. ${ }^{57}$

Under Tsar Nicholas I (1825-1855), this massive army would reorganize in an attempt to both capitalize on its Napoleonic successes and administer the resulting hugely inflated force ${ }^{58}$ Some limited efforts at reform were undertaken by Russian military thinkers in the wake of the Napoleonic Wars, as Russia, unlike most of her European counterparts, did not demobilize the huge forces she had raised during the course of the conflict, necessitating the continued management of a burdensome wartime force. The Russian military "maintained her forces under arms at three times their pre-war peacetime size."59 Likely to cope with this, military legislation was codified in 1839 in an attempt to better organize the administrative structures of the army and navy. The Ministry of War now had under it a Department of the General Staff, an Inspector's Department, a Medical Department, and Auditoriat Department. These were managed by a Military Council, of which the Minister of War was chairman. Engineering concerns, the artillery, military colonies and the sections for the Commissariat and Provisions also

\footnotetext{
${ }^{56}$ Frederick W. Kagan, "Russia's Small Wars, 1805-1861," in The Military History of Tsarist Russia, eds. Frederick W. Kagan and Robin Higham. (New York: Palgrave, 2002), 133.

57 Ibid.

58 Alexander Marshall, The Russian General Staff and Asia: 1860-1917, (New York, Routledge, 2006$), 5$.

59 Ibid.
} 
garnered their own departments.$^{60}$ The Active Army commander, Guard's commander, Grenadier's commander, the General Master of Ordinance and the General Inspector of Engineers "all enjoyed the right to report directly to the Tsar and not through the Minister of War, ${ }^{, 61}$ despite that minister's chairman position on the Military Council. This caused extreme centralization, with local commands having little authority to push orders down or receive reportage. ${ }^{62}$ While it could be seen as a move into modernity to codify the structure of the military, the reality behind this move was confused and inefficient. These reforms served only to create more bureaucracy at the higher levels of command, rather than changing core facets of the Russian military such as training or operational art.

The complexities and inefficiencies of this system, both before and after the 1839 reforms, made command and control difficult. Fiscal policy was almost impossible to implement with any sort of authority, even after some light reform attempts in the early nineteenth century. The Ministry of War would send Imperial finances thoroughly into debt through fractured logistics and the stubbornness of ranking officers with too much individual fiscal authority ${ }^{63}$ While the Caucasus War was on the backburner in the $1830 \mathrm{~s}$ but still costing money, rebellion in Poland led to a significant increase in debt. After only three years of fighting in Poland, 1831 "was financially the most difficult year compared to those previous, ${ }^{, 64}$ in terms of spending versus income, resulting in an overall debt of 823 million rubles in 1832. In the aftermath of the Crimean War the administration struggled once again to pay for costs of the conflict. In 1856 the

${ }^{60}$ Curtiss, The Russian Army, 98.

61 Ibid.

62 Ibid., 99.

${ }^{63}$ Ibid., 100.

${ }^{64}$ I.S. Biloh, Finansy Rossii XIX Stoletiia: Istoriia Statistika, Tom 1 [Finances of Russia XIX Century: History Statistics] (Saint Petersburg, 1882), 189. 
government fiscal projections placed spending at 271,516,000 rubles. These projections ended up falling far short of the mark, with real spending reaching 523,300,000 rubles, mostly due to military matters. ${ }^{65}$ This example shows that military planning and the high command authorities were largely out of touch with military realities on the ground in various theatres of war. Plans and estimates were made in Moscow without any significant input from regional, let alone tactical or operational, commanders who would have a better understanding of a given military situation.

\subsection{The Impact of Serfdom and Societal Issues on the Military System}

Some scholars point to societal issues, predominantly serfdom, as the chief cause of maldevelopment in Russian military thought. Serfdom and the estate system that perpetuated it may have allowed for ideas by older, conservative, noble, and higher ranking officers regarding the capabilities of the individual peasant-soldier. Officers who were a part of the serfdom system felt that Russian soldiers made perfect Napoleonic troops, with a slavish obedience to orders and remarkable discipline under fire. Often these traits proved to be true, such as in the defense of Sevastopol in the Crimean War. ${ }^{66}$ Modern and non-Napoleonic offensive tactics called for a much greater degree of individual thought by soldiers. Soldiers had to be able to make tactical decisions regarding movement and the application of their firepower, ${ }^{67} \mathrm{a}$ far cry from the rigidity of the system pursued by the Russian military. The supposed ideal nature of Russian troops within Napoleonic doctrine likely made it that much harder for officers to part with.

\footnotetext{
65 Biloh, I.S., Finansy Rossii, 25-26.

66 John Curtiss, Russia's Crimean War (Durham: Duke University Press, 1979), 85.

${ }^{67}$ Kaushik Roy, The Army in British India: From Colonial Warfare to Total War, 1857-1947 (London:

Bloomsbury Academic, 2013), 40.
} 
Serfdom had allowed for some military success, as it enabled Russia to construct a huge military with long troop retention periods (life down to 25 years) ${ }^{68}$ Peter Paret agrees that despite these advantages, Russian commanders in the nineteenth century "failed... to take advantage of the potential for tactical innovation that the reliable Russian peasant soldier afforded them.. ${ }^{99}$ This analysis is based on ideas regarding the bravery and steadfastness of the Russian soldier, traits that did prove to make them effective Napoleonic soldiers, able to maintain discipline and formation under heavy fire. Curtiss in The Russian Army Under Nicholas I agrees that serfdom likely had a huge impact on the thought and theories that contributed to deep-seated conservatism, which alienated academics, within the Russian military establishment. Curtiss states that "perhaps the ideas, whether correct or unsound, that the professors of the Military Academy held were not of great importance, for they seem to have had little effect upon the army as a whole"70 and that "the dominant attitude in the Russian army was highly discouraging to military scholarship.".71

68 Walter Pinter, "Russian Military Thought: The Western Model and the Shadow of Suvorov" in Makers of Modern Strategy: From Machiavelli to the Nuclear Age, Peter Pare ed. (Oxford: Oxford University Press, 1986), 355.

${ }^{69}$ Ibid., 356.

70 Curtiss, The Russian Army, 117.

71 Ibid., 118. 


\subsection{The Stagnation of nineteenth century Russian Military Thought and Academics}

These attitudes caused serious lapses within Russian military academics and theory. The following section will explore the reasons behind Russian military-academic stagnation and their impact on the military as a whole, both during the Caucasus and Central Asian Wars. Many of these issues were so deep seated that it would take decades before they could begin to be identified and rectified. Leading military thinkers were still referring to the ideals of Napoleonic warfare in the early twentieth century. It will become evident that the Russian military academic world was one that largely refused to adapt, even through numerous conflicts and attempts at reform.

A serious issue within Russian academic military study was that it was aimed predominantly at Europe. Indeed, the study of war in an Asiatic setting was largely ignored. Marshall notes that even in 1879, after decades of constant war in the Caucasus and Central Asia, of 3,297 books at the Staff Academy only 100 were categorized as "wars in Asia from ancient times to the present era."72 It is likely that a primary reason for this European focus was the applicability of Napoleonic tactics there, and for their history of success in that region. It would have taken a significant break with what was Russian military-academic tradition to enable a meaningful re-focusing of study towards Asia, despite Russia's many and longstanding engagements there. It will become plain that even when Russian military thinkers did deviate from this European, conventional tradition, they were more often than not ignored, and their ideas seldom made their way down to a tactical level where they might impact operations in the Caucasus in a beneficial way.

\footnotetext{
72 Marshall, The Russian General Staff, 47.
} 
Count Dimitri Miliutin, an officer of a reformist attitude who would eventually be partially responsible for the conclusion of the Caucasus War, was responsible for many of the reforms in the nineteenth century. However, "his actions were continuously challenged by more conservative groups within the military and state bureaucracy."73 Even after many of Miliutin's reforms, such as increasing the entrance standards for military academies in the $1870 \mathrm{~s},{ }^{74}$ Napoleonic era tactics remained the preferred base for the instruction of strategy and tactics. Officer as well as soldier training continued to fall back on to the fundamentals of Napoleonic warfare, even at the height of Russian expansion in Central Asia. ${ }^{75}$ Van Dyke in Russian Imperial Military Doctrine and Education calls facets of strategic exercises "dominant and... traditional" in their "reliance on the legacy of the Napoleonic era."76 General Dragomerov, a central figure in the training and educational facilities of the Russian military in the late nineteenth century, strictly adhered to the Suvorovian ideal "that the key to military success rested in the [Napoleonic] training and morale of Russian soldiers" and that "all-powerful General Staff officers... would destroy the chemistry between rank and file that was vital to victory in combat." ${ }^{, 77}$ Marshall points out that the level of military thought and study only really reached a point at which it could produce effective general staff officers in the 1880 s and onwards ${ }^{78}$ too late to have any real impact on the Caucasus campaign. Dragomerov's views continued to prevail over the ranking officers responsible for the

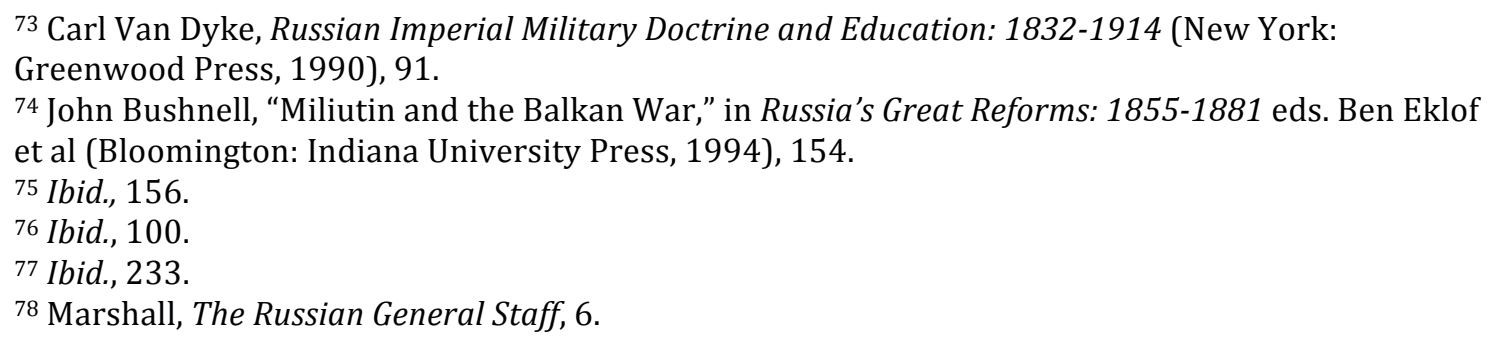


Russo-Japanese War of 1904-5. General Aleksey Kuropatkin was still then arguing that the General Staff needed to be integrated into "a unified command structure to empower them as they moved troops on and off the battlefield." ${ }^{79}$ Dragomerov failed to see that the numerous issues within the training of Russian troops made that theory based on that training unworkable anyways. The reader will see the same strategic and tactical stagnation plagued commanders and troops in the Caucasus War and for much of the nineteenth century.

There were some unique military thinkers who saw the error in constantly looking backwards into history for military theory. The works of Lt. Col. A. I. Maksheev, written while he was teaching at the Staff Academy in the 1840s-50s, reveals him to have been a deep thinker on issues regarding Russian identity, what he saw as Russia's role, and how better to accomplish Russian goals. Maksheev's ideas are precisely the type that might have had a positive impact on the conduct of the Caucasus War, had the greater military establishment not ignored him. His is a typical example showing that the Russian military was certainly capable of producing thinkers who looked outside the conventional box, but failed completely to implement any of these ideas on the planning table, let alone on the ground.

Maksheev was in no way a liberal, and indeed he espoused typically expansionist ideas, believing that it was Russia's destiny to bring the apparent light of Western and European civilization to the East and Asia. He stated that "in borrowing the seeds of civilization from the West, it [Russia] carries them away to the East," and that "maybe

\footnotetext{
${ }^{79}$ John W. Steinberg, "The Challenge of Reforming Imperial Russian General Staff Education, $1905-$ 1909" in Reforming the Tsar's Army: Military Innovation in Imperial Russia from Peter the Great to the Revolution, eds. David Schimmelpenninck Van Der Oye and Bruce W. Menning (Cambridge: Cambridge University Press, 2004), 233.
} 
this is the chief purpose of our historic homeland." ${ }^{80}$ Maksheev presented logical but novel ways by which Russia might better accomplish expansionist ends. Maksheev wrote that Russia's “territorial, economic, and political relation with the West is becoming more and more established... in the East, although we have reached significant results, we cannot say that our mission is accomplished and our aspiration is over." Regarding the East, he concludes that "the study of anything that might explain it must be paramount." ${ }^{81}$ Maksheev argued for an adjustment in interest and study, pointing out that the East and Asia might contain novel and more appropriate ideas for expansion therein, including military reform.

This deeper philosophy on identity and role carried into Maksheev's interpretation of military scholarship and its then current directions at the formative general staff Academy. Maksheev pointed out that the Academy based its curriculum "on entirely military science from the West," and that there was not paid "sufficient attention to the peculiarities of our Russian historical experience and mission," ${ }^{\prime 82}$ referring to the Eastern direction of Russian military action. He stated that "the academy talks a great deal, for example, about Turenne and Montecuccoli (Renaissance French and Italian military authorities) and so on and... not one word is said about Chinggis Khan, Tamerlane [or] Nadir-Shah (successful Eastern and Asian campaigners)." ${ }^{93}$ Marshall points out that on some rare occasions, thinkers like Maksheev were not entirely ignored. Maksheev is credited with compiling the first work on steppe tactics, though Marshall notes that this

${ }^{80}$ A. I. Maksheev, Puteshestviia po Kirgizskim Stepiam i Turkestanskomu Kraiu [Journeys in Kirgiz Steppes and Turkestan Region] (Saint Petersburg: Voennaia Tipografiia (v Zdanii Glavnogo Shtaba), 1896), 3.

81 Ibid.

${ }^{82}$ A.I. Maksheev, in Alex Marshall, The Russian General Staff, 48.

83 Ibid. 
work was, once again, overshadowed by those dealing with Europe. ${ }^{84}$ Works like Maksheev's did eventually lead to some practical training on the subject of what could be seen as counter-insurgency operations, discussing small unit tactics and unconventional formations and movements. ${ }^{85}$

General M.I. Ivanin, a contemporary of Maksheev's, also stressed the unique nature of Asian combat, which "demanded special techniques and careful study." Another officer, A. I. Astaf'ev, “believed that many aspects of Napoleonic military art no longer corresponded with modern developments, including the introduction of rifled shoulder weapons. ${ }^{, 87}$ The adoption of such a weapon would mean a full break with Napoleonic tactics, and would have forced the learning of a new method of fighting on the Russians. As we have seen, this is something they were not willing to do at any point during the Caucasus War. To a large extent, in following a tradition of ignoring forward thinking military minds, Maksheev and his contemporaries like Medem, Ivanin, and Astaf'ev, who broke the military-academic mold, were largely neglected by the greater establishment. Studies of Asia and the unique military challenges within would not be undertaken again on a scale similar to those pursued by these thinkers until the $1890 \mathrm{~s},{ }^{88}$ long after they might have been useful within the Caucasus War or the conquest of Central Asia.

\footnotetext{
${ }^{84}$ Marshall, The Russian General Staff, 47.

85 Ibid., 50.

86 Ibid., 47.

87 Menning, Bayonets Before Bullets, 8.

88 Ibid., 102.
} 


\subsection{The Results of The Russian Military System and the Napoleonic Dynamic: M. S. \\ Vorontsov}

A cumulative example of how this system crafted those leaders within it lies in the case of General Prince M. S. Vorontsov, who was given overall command of the mission to Dargo, which will be the focus on the next chapter. By 1845, the Tsar was growing impatient with the lack of progress in the Caucasus War. He wrote a memorandum espousing his views on the subject, which would form the basis for formal orders to be carried out in the theater of war in that year. Nicholas stated simply that the major goals of 1844 , being "to fix the troubles of 1843 " had not been reached. "What is left for us," he continued, "and what has not been done in 1844 are these three points: To defeat Shamil's forces, to penetrate the center of his territories, and to establish Russian authority there. ${ }^{" 89}$ The simplicity of the Tsar's remarks points perhaps to a lack of will in the governing of prior stages in this conflict. Then again, perhaps a simple restatement of the end goals was seen as a necessity after so many years of fighting. The Tsar, being an amateur military enthusiast, did elaborate on how he felt these goals should be accomplished, describing a pincer movement to flank Shamil's positions in the Caucasus, pointing out that any other methods would cause difficulties and take too much time..$^{90}$ This simplistic interpretation of tactics was likely not overly helpful to his top generals, but the expectation was equally likely to have been that those generals would take care of the details. To that effect, the Tsar appointed General Prince Vorontsov, of Napoleonic

\footnotetext{
${ }^{89}$ Nicholas I, "Zapiska Imperatora Nikolaia I o Voennykh Derstviiakh na Kavkaze [A Note by the Emperor Nicholas I on the Military Actions in the Caucasus]," Russkaia Starina XLVIII, 10-12 (1885): 209.

${ }^{90}$ Ibid., 210-11.
} 
fame, to the chief position in the war, granting him field command and the position of viceroy of the entire region.

Vorontsov was known as a skilled Napoleonic soldier, with a career full of victories. As a senior General, he had held numerous operational commands, and had fought with legendary figures such as Suvorov against the Grande Armée in Europe. Vorontsov would eventually express his fears at being appointed commander of this renewed Caucasus effort. He felt unprepared for the endeavor, as is shown in his writings prior to taking command. When Vorontsov was given command of the region in 1845, Russian strategists on the Caucasus were growing impatient but continuing to conduct the war as they had since General A.P. Ermolov's departure from the theater in the late 1820s, sending periodic and significant columns into the mountains to try and draw Shamil into battle.

Vorontsov, for all of his previous success, immediately recognized that the Caucasus Theater represented a novel challenge for Russian forces. A lack of confidence is particularly notable within correspondence with Ermolov. Certainly, within the Caucasus Theater, Ermolov was one of the most experienced commanders, and had been present when the Caucasus War began to take the shape it would maintain until its conclusion. Yet he was actually relieved of his duties and replaced by Nicholas. That Vorontsov thought it necessary to write him shows the Russian military community still regarded him as a definitive Caucasus authority. Vorontsov credits Ermolov, telling him "you know well this place and all the circumstances of this location and this war"91. If Vorontsov was not confident in his own abilities in the Caucasus, it appears that he was

${ }^{91}$ M. S. Vorontsov, Letter to A. P. Ermolov, January 1845. Russkil Arkhiv 2 (1890): 162. 
fully confident that Ermolov was the definitive expert on the region. As while Ermolov had not won the war, the reader will see that his letters to Vorontsov show that he had a unique and liberal understanding of military practices. He would even go so far as to suggest that retreat was sometimes needed, ${ }^{92}$ a concept unthinkable to a steadfast Napoleonic officer.

Prior to engaging in the summer's campaign in 1845, Vorontsov appears to have sought consultation from other generals with experience in the region. Vorontsov himself stated that he "was also surprised...to hear about my appointment to the Caucasus," an appointment he accepted "not without fear."93 The reasons for this fear were likely based on the fact that Vorontsov recognized his lack of experience this special type of warfare, understanding that while he had certainly been successful on a conventional field of battle that within the Caucasus "there is a lot to do... and this region, especially in its current state, is absolutely unfamiliar." 94 Prior to the Crimean War, generals experienced in the Caucasus were expressing cautious opinions regarding the success of any plans therein. Shamil was then experiencing some of his greatest victories, and after forty years of war the Russians had gained little. ${ }^{95}$ Vorontsov consulted with an experienced Caucasus commander, General Frietag, prior to acting. Having gained from him a better appreciation of the war on the ground, Vorontsov's confidence in his mission appears to have lessened somewhat: after this conversation

92 A. P. Ermolov, Letter to M. S. Vorontsov, August, 1845. Russkĭ Arkhiv 2 (1890): 173.

93 Vorontsov, Letter to A. P. Ermolov, 162.

94 Ibid.

95 Robert F. Baumann, "Russian-Soviet Unconventional Wars in the Caucasus, Central Asia, and Afghanistan," Leavenworth Papers: Combat Studies Institute, US Army Command and General Staff College 20 (1993): 20. 
with Frietag, he wrote that "I do not dare to hope for a great success of our company, but I will do, of course, all I can..."96

The simplicity of the Tsar's orders to Vorontsov regarding a pincer movement correspond to the advice the former rendered to his subordinates when observing military training maneuvers, where he consistently focused on appearance rather than substance. The Tsar knew he wanted the Caucasus War to end, but provided little in terms of additional or novel support, and did not propose any radical suggestions that might differentiate this proposed operation from the many that preceded it. In the field this probably had little effect, and in any event the Tsar considered Vorontsov as a thoroughly able and experienced commander capable of creating and carrying out a plan $^{97}$ that might bring victory.

While the 1845 memorandum drafted by the Tsar represents a restatement of the aims for the war, true political will for an end state in the Caucasus region would not come until the signing of the Treaty of Paris after defeat in Crimea. The efforts that resulted from the 1845 memorandum failed to change the military equation. New commanders and feelings of a renewed mission only have so much effect, and the reader will see that this was not enough to garner a decisive victory.

At a theoretical level, it appears that the Russian military was unsuited for the rigors of combat in the Caucasus. These issues, as the reader will see, had a significant negative impact on the performance of the Russian military in the Caucasus War. The discussion above represents strategic and higher level problems. These problems manifest themselves in many aspects of the performance of the military, and what follows

\footnotetext{
96 General Vorontsov in Baddelely, The Russian Conquest of the Caucasus, 386.

97 John F. Baddeley, The Russian Conquest of the Caucasus (New York: 1969, Russell \& Russell), 386.
} 
is a discussion of these specific issues. These issues created problems with practical and tactical impacts in the field, as will be seen at the battle of Dargo. 


\section{Chapter 3: The Caucasus Theatre and the Battle of Dargo}

\subsection{Introduction}

This chapter will look in detail at the 1845 Battle of Dargo as a case study of the poor suitability of the Russian military for combat in the Caucasus. Rather than rely heavily on a narrative of the event itself, the chapter is structured around key areas of Russian military art and how they affected the battle. The aim is to provide the reader with an understanding of particular elements of military practice, to identify key problems as they developed within the Russian military system, and to show the tactical or operational implications on the battle at Dargo. It will become evident that the Russian military system had created an army so reliant on outdated techniques that it was quite unable to effectively deal with a numerically inferior foe on territory with which they ought to have been familiar with after decades of war there. The evidence discussed below all points to officers who were not trained to fight in the Caucasus environment, and to the impacts of the implementation of a system largely inappropriate for the terrain, the enemy, and for Russian soldiers.

\subsection{Operational Leadership}

The operational level of leadership was, and still is, a key piece in any military initiative. Operational leaders are those who make the key decisions, and form the overall strategic plans for an operation such as those examined in this work. They are not generally concerned with large scale, geo-political strategic aims but rather with specific missions. Operational leaders hold the ultimate responsibility for the conduct their mission. As we have seen, Vorontsov was granted operational charge of the Dargo 
mission. It is important to understand to what extent Vorontsov was a product of the above mentioned high level and military theory developments. It is apparent from his correspondence, and from the outcome of the Dargo mission, that he in many ways represented a manifestation of the problems within early nineteenth century Russian military theory. Understanding how the Russian military operated at a theoretical and strategic guidance level, choosing Vorontsov for command of the Dargo mission makes sense. This mission was meant to be the Tsar's final blow in a long and costly military adventure, and from within the Russian military system as it was, Vorontsov had all the traditional credentials of a perfect soldier. In a system so concerned with Napoleonic tactics, the obvious choice for command of any important mission is a man who had mastered the application of euro-centric Napoleonic warfare. Vorontsov had defeated Napoleon's troops and performed well in numerous other smaller Russian campaigns against the Turks, who fought a much more conventional battle than the Caucasus mountaineers. An obvious choice for leadership in any major military initiative, yet a choice that shows just how poorly high political thinkers understood the region. What is interesting but not surprising about Vorontsov's appointment is that there seems to be little evidence that it was disputed. Who else could the Russians place in command of the Caucasus theatre? None of the generals who preceded Vorontsov had had any remarkable success in quelling the violence in the region. This further proves that the Russians failed to see that the Caucasus represented a novel challenge that might require novel methods, even while Vorontsov himself admitted he was unready for war there. Despite decades of fighting, the Tsar was unable, or simply did not think it necessary, to find a more suitable commander than one who had little experience there. 
Vorontsov's intelligence shines through in more letters written to Ermolov, and he seems to almost implicitly acknowledge that the system had failed to prepare him for war in the Caucasus. He understood that this was not a war in which he was prepared to excel. The lack of confidence expressed in his letters went beyond a simple lack of understanding of the Caucasus. To Ermolov, with whom Vorontsov must have shared a bond of respect, he states candidly that "to refuse this appointment was impossible for me...I did not choose myself, and I can only be responsible for my effort and good will, I can not be responsible for anything else."98 The hesitation shown by Vorontsov would not have boded well for any campaigns he launched, and he would actually write to Ermolov: "I proclaim that this appointment is more than I can bear." 99 Vorontsov went on to express his uncertainty with how precisely the Russians would engage their opposing forces, stating that "we will be looking for Shamil, however, only God knows if he will give us a chance to harm him." What he was sure of was that if a chance to engage Shamil appeared it would be used. ${ }^{100}$ What is not apparent is any evidence that indicates that Vorontsov had any idea as to how to actually find Shamil, or how precisely to fight him. The latter is particularly interesting, and is again likely a result of Vorontsov being a product of the Russian military system that so disregarded the theater and the application of strategy and tactics within it. Vorontsov immediately began to mitigate and qualify any expected results. He wrote that "they expect too much from our expedition back in Russia, [and] I hope we will not do any damage," and also that "it can

\footnotetext{
98 M. S. Vorontsov, Letter to A. P. Ermolov, January 1845, Russkil Arkhiv 2 (1890): 162.

${ }^{99}$ Ibid.

100 Ibid., 164.
} 
happen that we will not do any good either, [and] I hope we will not be blamed for that."101

It is true that an able commander might have feelings similar to those of Vorontsov's prior to an operation, and be able to control them in leading soldiers in war, but Vorontsov's letters show that even the most able conventional commanders found themselves unable to see a victory in the Caucasus. A commander who is able to seize the moment, confident in his skills in that particular type of combat, is more likely the type of commander who would bring a favorable end to an engagement therein. ${ }^{102}$ Vorontsov's letters do show that he did understand that the conflict would be different from what he knew, and that it would be different from how the Russian population (or at least individuals whose opinions Vorontsov cared about) perceived it as well. It will become evident that despite knowing these things, he found himself unable to come up with novel ways to tackle the problems before him.

General Ermolov, writing back to Vorontsov, displayed that he understood from his personal experience in the early nineteenth century that the region was difficult to operate in, and that he understood that by the 1840s it had become even more difficult. Ermolov described his situation as one of comparative simplicity to Vorontsov's, accurately stating that while he ran the theater, the "mountaineers were not allowed to agree with one another, and there was no religious fanaticism to unite them; the disobedient were punished one by one, therefore without any large difficulty."103 Ermolov would have fought an insurgency of somewhat less organization, and likely less

\footnotetext{
101 Vorontsov, Letter to A. P. Ermolov, 164.

102 Gen. Charles C. Kurlak, "The Strategic Corporal: Leadership in The Three Block War," Marines Magazine (1999): 18-19.

103 A. P. Ermolov, Letter to M. S. Vorontsov, 19 June, 1845. Russkil̆ Arkhiv 2 (1890): 166.
} 
motivation, as Shamil had not yet taken over as the leading figure in the fight against the Russians. Ermolov also warned Vorontsov of the new importance of public perceptions, something he never felt he had to deal with while in command. He tells Vorontsov that following the Napoleonic Wars "ended in the most spectacular way with the occupation of Paris and the resignation of France, the late Emperor could not help but conceal that the Caucasus had disobedient people, and people who dared to oppose the Tsar,"104 implying that the European War was purposely allowed to the public's focus. Ermolov states that this was the reason "everything that $[\mathrm{I}]$ did was not talked about, and was also concealed...." 105 This would obviously have made maintaining, if not gaining, a reputation out of the conflict much easier, and shows that in its early stages this war was thoroughly in the back of decision maker's minds. Vorontsov did not have that luxury, and actually would have had to deal with any remnants of Ermolov's time in the Caucasus while knowing that his every move would be observed and critiqued by both a domestic and foreign audience. The solution Ermolov called for was "success, or, if destiny refuses us success, we need fewer losses compared to what was until now."106

\subsection{Lack of General Staff and the Tactical Implications}

Vorontsov might have been more successful at Dargo, despite his lack of preparedness to command that operation, if he had had access to an institution that was maintained by most western European militaries, a General Staff. A General Staff was meant to provide a separate command structure outside of the direct authority of officers'

\footnotetext{
104 Ermolov, Letter to M. S. Vorontsov, 19 June, 1845, 165.

105 Ibid.

106 Ibid., 166.
} 
commanding units. Officers within a General Staff were generally selected for their intelligence and tradecraft, and were trained to be subject matter experts that could provide expert advice to high-level commanders about the implementation of various elements of warfare in varying terrain and circumstances. The Germans had been employing such a body since the time of Frederick the Great, using unattached officers to carry out delegated functions within engineering, logistics, intelligence, and any other tasks requiring specialization outside the direct commanding of troops. ${ }^{107}$

Marshall points out that since 1763, the idea of a general staff had been known to Russian military thinkers, but that its role was usually confined simply to that of the aid or entourage of a higher formation commander. ${ }^{108}$ The lack of early development in this area seems to be partially due to the Decembrist movement, wherein the officers of the Suite of His Majesty for Quartermaster Affairs (era acumen for General Staff) came into disfavor by virtue of the fact that no significant members of that body played a role in attempting to stop the revolt. The opinion was formed within the higher echelons of the Russian military administration that those officers who came up from the Kolonovozhatykh (School of Column Leaders), which at the time fed the fledgling general staff, could not be relied upon. The school was disbanded during the reforms of Nicholas I for this reason. This event, combined with the traditional "prevalent distrust of intellectuals" at a time so rife with revolutionary thought, meant that when the issue of the re-creation of a general staff did arise, reforms associated with it proved "to be drastic

\footnotetext{
107 Peter Hofschroer, Prussian Staff and Specialist Troops, 1791-1815 (DE: Osprey Publishing, 2012), 5. 108 Ibid., 4.
} 
and harsh."109 Menning states that Nicholas I was "obsessed not only with fear of foreign revolution but also with the dangers presented by malcontents within his own nobility and officer corps," ${ }^{110}$ referencing the post-Decembrist Uprising atmosphere.

The General Staff of any European army became a singularly important body in the nineteenth century. Alexander Marshall states that "the development of a doctrine best suited to penetrating the steppe and defeating nomadic tribal opponents depended implicitly not just upon firepower and political calculations but upon successive generations of military thinkers." "111 This would have fallen to a Russian General Staff, that body partially meant to be the keepers and developers of knowledge within a military, and to be the primary group for dealing with the ever increasing technical nature of combat, topographical concerns, logistics issues and intelligence. Russia's reputation as an extremely difficult military opponent was certainly not groundless, but all these victories went unanalyzed and then un-archived or codified. Marshall states that the improper use of what passed for a general staff in the first half of the nineteenth century meant that only a "few at the time drew long-term lessons from their tactical and doctrinal practices... [and] the production of military doctrine remained devolved down to the regimental level for much of the period." "112

In researching accounts of the battle at Dargo, no outside advice given to Vorontsov was located. Vorontsov was most likely forced to rely purely on his own

109 John Shelton Curtiss, The Russian Army Under Nicholas I: 1825-1855 (Durham, N.C., Duke University Press, 1965), 101.

110 Bruce Menning, Bayonets Before Bullets: The Imperial Russian Army, 1861-1914 (Bloomington: Indiana University Press, 1992), 7.

111 Alexander Marshall, The Russian General Staff and Asia: 1860-1917, (New York, Routledge, 2006), 4. 112 Ibid. 
interpretations of the ongoing situation to reach actionable decisions, and that he did not have the luxury of consulting experts, if indeed there were any.

The disorganized nature of the battle at Dargo seems to all point not only to a lack of a general staff function, but also provides a specific example of a lack of terrain study. It is probable that reconnaissance missions were carried out, but a general staff or related body would have conducted studies of the terrain and garnered generalizations from it before the Russians were engaged there. Time and time again, terrain would play against the Russians at Dargo. A young officer present at the battle, then Lieutenant Prince Dondukov-Korsakov, described a situation wherein his group was halted in front of a mountaineer barricade. He stated that "at that time the advance guard...stopped because of the overwhelming fire around them from the trench systems, and deployed two mountain guns to fire at the positions" but that the " due to the steepness of the cliffs our line [of men] could not be lowered into the slopes and the troops crowded on the road."113 This placed the body of troops under "brutal crossfire," emanating from "highlanders shoot[ing] from the bottom of the ravine and their positions of rubble." "114 The tactical situation at this point was clearly in favor of the mountaineers, who, already having stopped the first mounted attempt at storming their position, now had a significant Russian force crowded on an open road, unable to move or effectively return fire. The terrain stopped the Russians from deploying into more effective positions, being too steep, and their lack of training at countering light defensive positions appears to have destroyed their ability to formulate a quick alternative plan. The use of mountain guns

\footnotetext{
113 A. M. Dondukov-Korsakov, "Moi Vospominaniia [My Memories],” in Starina i Novizna: Istoricheskĭ Sbornik, Book 6 (Saint Petersburg: Tipografiia M. Stasiulevicha, 1908), 118. 114 Ibid.
} 
could have proven effective here, but Dondukov-Korsakov notes that within "a few minutes all the men serving the guns were killed and the young artillery officer in charge of the battery was hit by two bullets which broke his spine."115 This encounter says many things about the abilities of the Russians at this battle, but it also proves that not maintaining a body of officers devoted to the study of terrain did not work in their favor. This is particularly true given that the Russians had been operating in the region for decades, which rules out a lack of reconnaissance, instead pointing back to an inability to catalogue and implement knowledge gained. Had Vorontsov's forces understood the implications of the terrain in this particular instance, they could have formulated a far more effective plan for its seizure.

\subsection{The Tactical Impact of Poor Officer Education}

The state of development in the Russian military academic world was not at point by the Caucasus War where it might have had a positive impact in that conflict. Even during the post-Crimean War era, it was determined that 74 percent of military officers entering the army had not completed education at a military academy. ${ }^{116}$ According to Ray in "The Imperial Russian Army Officer," officers tended to come from one of four sources in the first half of the nineteenth century. They could be graduates of a military academy; cadet corps or Guards school graduates; non-commissioned members who were brought up from the ranks; or volunteers who usually came from the nobility and were

\footnotetext{
115 Dondukov-Korsakov, "Moi Vospominaniia,” 118.

116 Oliver Allen Ray, “The Imperial Russian Army Officer," Political Science Quarterly 76, no. 4 (1961): 579.
} 
promoted to officer rank. Between 1825 and 1850, of 50,567 officers only 14,415 graduated from any sort of academic military institution. ${ }^{117}$

The Russian officer corps was fundamentally responsible for shaping the form and substance of the Russian military throughout the nineteenth century. The impact of their actions on the substance of the Russian military was significant. After all, the Russian army, being structured like any European military, was designed to have much of the work or fighting done by common soldiers led by officers. This section will show that the problems inherent to the officer corps trickled down with far-reaching and significant effects at the level of the common soldier. The problems at the officer level had dramatic consequences, affecting every aspect of the soldier's life, from daily routine, education, training, and in the conduct of battle or warfare. Given how integral this group was to the Russian military as a whole, an understanding of how they were educated or not educated is important to any understanding of how the group functioned in the Caucasus War and in Central Asian campaigns.

Nicholas I, as a part of his 1830s light reforms, which included the codification of military structures discussed earlier in this work, decided that a revamp of the military education system was needed. He asked General Jomini, court military historian and theorist, to draw up plans for a military academy based along provisions provided by Nicholas. ${ }^{118}$ Jomini promptly followed the Tsar's ideas, coming up with a proposal aimed at providing an academy to issue lessons to officers in the higher thought of military action. Jomini stated that "a good general staff is as important to the army as a

\footnotetext{
117 A. V. Federov, in Ray, “The Imperial Russian Army Officer,” 580.

118 Carl Van Dyke, Russian Imperial Military Doctrine and Education: 1832-1914 (New York: Greenwood Press, 1990), 1.
} 
good ministry is to the state." ${ }^{119}$ As we have already seen, Jomini's advice regarding general staffs was not implemented in time for the Caucasus War, and the school that resulted from his actions failed to produce adequately and broadly trained officers, despite eventually being called the Nicholas Academy of the General Staff.

Once the Tsar approved of "a wider military-educational institution," ${ }^{120}$ Jomini drew up plans in the early 1830s which he envisioned would aid in the education of the entire Imperial Officer Corps, "from staff Captains to general officers." ${ }^{121}$ The curriculum consisted of one year of generalist courses, followed by intensive study in the areas of terrain and tactics, grand tactics, military history, opposing forces in Europe and a study of fortification, administration and false doctrine. ${ }^{122}$ It is obvious from the content of the curriculum that the thinkers behind the academy, which was to be called the Nicholas Academy of the General Staff, were not planning on breaking with traditional Russian military thinking. Indeed, an entire portion of the core study was directed at opposing forces in the forms of Western European militaries, even while Russia was consistently engaged on other fronts against enemies of rather different types. It should be noted that one of the predominant influential figures during the early years of the academy did indeed attempt to push the curriculum beyond traditionalist thinking. Baron von Medem took post as lecturer of strategy, military history and military literature in 1833-4, espousing the idea that one cannot derive concretely applicable rules from military history. This was in direct juxtaposition to the views of the academy's founder, Jomini. Medem specifically pointed out the folly of Jomini's adhering to a history-

\footnotetext{
119 Van Dyke, Russian Imperial Military Doctrine, 4.

120 Ibid.

121 Ibid.

122 Ibid.
} 
centric methodology based on systems founded by Frederick the Great and Napoleon for the development of rules. A strict adherence to these types of rules did not take into account factors such as variable geography, or rapid advances made in military technology. ${ }^{123}$ The influence of this singular thinker was not significant enough to render any dramatic reformist approaches to military thought, as the events of the Caucasus War prove.

These unorthodox theories were observed by a student of Medem, D.A. Miliutin. Miliutin may have learned from his time at the Academy, but it is likely he learned more from the traditional Russian method of teaching young officers by the simple experience of being present during battle. ${ }^{124}$ These experiences seem to be a more likely candidate for granting Miliutin some of his genius, or at least his appreciation for out of the box thinking within a generally very conservative body. Unfortunately, liberal ideas set forth even at the foundational stages at the general staff academy would not be heeded in time to have significant impact on the curriculum of that institution. Medem's ideas regarding the inappropriateness of strict adherence to Napoleonic doctrine being ignored by almost all echelons of the military establishment was a common type of incident, the likes of which would occur again and again both within the general staff academy and the Tsarist military as a whole.

The actions of the officers at Dargo consistently point to a lack of uniform educational background, with officers repeatedly making poor decisions displaying a lack

\footnotetext{
123 Van Dyke, Russian Imperial Military Doctrine, 10-11.

124 For an explanation of this approach see chapter by Frederick W. Kagan, "Russian Military Reform in the Age of Napoleon" in David Schimmelpenninck Van Der Oye and Bruce W. Menning's Reforming the Tsar's Army: Military Innovation in Imperial Russia from Peter the Great to the Revolution (Cambridge: Cambridge University Press, 2004), 189-204.
} 
of understanding of basic tactics, or an advanced and unwavering understanding of outdated ones. This is displayed early in Vorontsov's mission by one of his senior commanders, General Passek. Vorontsov set off as per the Tsar's orders in June of 1845 leading an expedition towards Dargo, where Shamil was known to have had a residence. ${ }^{125}$ The ponderous force, consisting of 21 infantry battalions, 4 companies of engineers, 2 companies of sharp shooters, 16 squadrons of cavalry, and 46 guns, in all totaling 18000 men, followed along a route used by General Grabbe on an ill-fated offensive in 1842 .

On June 6, drawing near Dargo, the expedition ran into its first point of trouble. It came after the successful attack of a high position by General Passek, who was known to be impulsive in his command. Passek took his force uphill against a larger number of mountaineers and forced their retreat. In the excitement of the easy win, and failing to understand the impact of his surroundings, which presented very hilly geography, Passek took his force 10 miles ahead and became isolated when the heavier main body and logistics compliment could not keep pace. Nature would strike the first real blow to the Russians here, as the temperature in the mountains plummeted and killed 500 horses during the course of Passek's force's isolation from the main body of troops. Vorontsov caught up, without his logistics train, on the $11^{\text {th }}$ of June..$^{126}$

Shamil, now knowing how strong his enemy's artillery compliment was, made the sound decision to abandon a fortified position he had prepared near the town of Andee. Shamil had his forces fight a withdrawal action meant to harass the Russians as they made the approach from Andee to Dargo. Passek's actions indicate that he either lacked

\footnotetext{
125 John F. Baddeley, The Russian Conquest of the Caucasus (New York: 1969, Russell \& Russell), 387. 126 Ibid., 389.
} 
a basic understanding of tactics, or that he simply chose to ignore them. Were this an isolated incident, one might give Passek the benefit of the doubt and label him as a bold and aggressive commander, but the reader will see that decisions like these are made consistently during the Dargo campaign. The costs of Passek's inability to apply basic tactics cost the Russians dearly. From the consulted sources, it is not known if these horses represented a cavalry compliment or a logistical one, but either way, their loss represents a serious handicap for the Russian force early on in the battle. Passek's force rushing forward also allowed Shamil's scouts to gain a more accurate understanding of the Russian force.

\subsection{Field Training and Other Habits as they Affected Competency}

Many officers actually attended institutions of lesser quality, such as cadet schools, or none at all. These officers came from many walks of life, but John Bushnell has noted several common tendencies. Bushnell states that drinking was such a fundamental part of officer life that "there is literally no officer memoir, published or unpublished, that does not report either individual cases of drinking to incapacitation or a uniform pattern of heavy drinking." 127 Officers drank for a variety of reasons, many likely beyond the scope of this or Bushnell's work, but chief among the reasons seems to be boredom. Officers posted in locales on the edge of empire drank because there was nothing else to do, but officers who were posted in Europe drank for the same reasons. ${ }^{128}$ Even officers who were posted to large cities are recorded as having frequently been

\footnotetext{
127 John Bushnell, “The Tsarist Officer Corps: 1881-1914,” The American Historical Review 86, no. 4 (1981): 755 . 128 Ibid., 756.
} 
drunk in public places. Bushnell states that drinking would not have had a negative effect on a career, and that it was common enough that officers failed to notice genuine alcoholics among their ranks. ${ }^{129}$ It is hard to imagine that this behavior, either directly or indirectly, did not have a negative effect on the smooth running of the military. Bushnell states that problems such as drinking actually "manifestly subverted efficiency."130

\subsection{The Lack of Appropriate Training}

Serious problems existed with the way Russian officers spent their on-duty time as well. Training, in a general context, was aimed at ensuring grandiose exercises went smoothly. The Russian troops trained almost exclusively at close order drill, at which Curtiss states they were unusually good. ${ }^{131}$ For his part, Nicholas I was a great admirer of all things military. As such, annual maneuvers were played out wherein the Tsar could observe what was in effect his well-oiled marching machine, but the troops and their officers understood that the most important factor was the appearance of quality rather than the actual practice of it. The exercises, being held in the same locales each year, became familiar territory and it seems that there were some rather conveniently placed trees that would indicate the start of a march, or the point at which a passing body of troops should perform a particular piece of weapons drill. ${ }^{132}$

Events like these were commonplace, and occurred when royalty was not present as well. They illustrate the attitudes towards the training of men at the time. Lt. General

\footnotetext{
${ }^{129}$ Bushnell, "The Tsarist Officer Corps," 755-756.

130 Ibid., 762.

131 Curtiss, The Russian Army, 118.

132 Lt. Gen. N.P. Glinoetskii, Istoriia Russkogo General'nogo Shtaba: Tom II, 1826-1855 [History of Russian General Staff] (Saint Petersburg: Military Printing House, 1894), 192.
} 
Glinoetskii, writing in 1894 his "History of the Russian General Staff," brings some interesting and relevant perspective to these cumulative annual exercises. He describes how locations were selected to facilitate the easy maneuvering of troops, large and open areas free of obstacles. The exercise in its entirety was planned, essentially choreographed, with the aim of producing and maintaining perfect tactical formations so apt for the Napoleonic exchange of musketry and artillery. Glinoetskii, who was himself an officer of the later General Staff, points out that one would be unable to find any reference to a General Staff body, after it was finally formed, within documentation regarding these exercises. General staff activities were relegated to the extreme background within the maneuvers. ${ }^{133}$ One can certainly see how this would be the case. There would not be too much for a professional general staff to do at an exercise that was choreographed to the extent of the ones carried out during the first half of the nineteenth century by the Russian military.

The results of consistently practicing choreographed, rehearsed exercises on well known and obstacle free terrain were disastrous in the Caucasus. It created a corps of officers only capable of exerting real control over their troops in what is essentially a terrain free environment, with easy lines of sight and communication and with plenty of room to maneuver cumbersome Napoleonic formations. The following evidence reveals that officers trained in these types of situations were unable to cope with the complexities at Dargo. Lieutenant Dondukov-Korsakov was present at the battle of July 6, when the expedition was only 4 or 5 miles from Dargo, and his memoirs reveal some interesting facts illustrating ill-preparedness for the terrain. Dondukov-Korsakov describes how,

\footnotetext{
133 Glinoetskii, Istoriia Russkogo General'nogo Shtaba, 193.
} 
when his forces were made to enter a more heavily wooded area, they encountered significant obstacles, in the form of "ancient trees, twisted sticks and fortified earth and stones." 134 Within these fortified positions, he states that the "highlanders could be seen through the leaves and trees as their silent weapons shone through the boughs, waiting for our approach." ${ }^{135}$ The mountaineers, adept in ambush tactics, were in this instance using them to slow the Russian advance rather than as a final defensive position. On this occasion the harassment by the mountaineers had some effect on Dondukov-Korsakov's formation, as its members made the poor decision to attack while still mounted on their horses. They soon discovered that the fortifications could only be jumped in some areas. ${ }^{136}$ Dondukov-Korsakov was attached to a group of chasseurs, a kind of light cavalry meant for quick shock actions or flank-probing reconnaissance on flat, even terrain, so it is understandable that they would be mounted. Dondukov-Korsakov was wounded while attempting to rescue a friend who had been shot trying to make it through the mountaineer position. ${ }^{137}$ A complete lack of understanding of how to attack even a rudimentary position, constructed of natural materials, shines through in this episode.

\subsection{The Strict Adherence to Napoleonic Doctrine}

Curtiss in The Russian Army Under Nicholas I describes the fetish present within the nineteenth century Russian military with rehearsal and regulation at great detail. The training of troops was based entirely upon regulation set down by army high command. Within the regulations were contained strict battle orders which were to be adhered to

134 Dondukov-Korsakov, “Moi Vospominaniia,” 116.

135 Ibid., 116-117.

136 Ibid., 117.

137 Ibid. 
during exercise, and, under an unsophisticated commander, battle. A. M.

Zaionchkovskii, writing in 1907 an examination of the Crimean War, discusses just how detailed these regulations were. They would go so far as to prescribe not only general locations of troop formations, but the precise intervals, measured in steps, between bodies of men. ${ }^{138}$ Apparently the regulations were a form of attempting to create a sort of formulaic reference. An officer who felt that there might be some particular need within a situation for a variation of the standard regulation could look up said variation, as the regulations contained variable cases. Within the regulations there existed formulas for defensive operations, offensive operations, and for when the situation was as of yet unclear to the commander. ${ }^{139}$ Essentially, these regulations represent a sort of cookiecutter approach to warfare, endowing a commanding officer with the opportunity to pick from several different formulas for application on the field, but allowing for little use of individual initiative or adaptation.

Zaionchkovskii goes on to state that these regulations and their cases had the illeffect of creating a sort of false command confidence in traditional battle lines, wherein leaders saw these formations as unbreakable in the field. ${ }^{140}$ The false command confidence based on adherence to regulation reached the highest levels of authority. Curtiss quotes Nicholas I as saying "it has turned out that everything we do in peacetime in training the troops is correct and necessary for wartime" when speaking about the success of Russian forces in Hungary in $1849 .{ }^{141}$ Further, the Tsar went on to criticize

138 A. M. Zaionchkovskii, Vostochnaia Voĭna: 1853-1856, Tom 1 [Eastern War: 1853-1856, Volume 1] (Saint Petersburg: 1907, Print Polygon: Saint Petersburg, 2002), 472.

139 Ibid., 475.

140 Ibid., 472.

141 Curtiss, The Russian Army, 115. 
those commanders whom he saw as having performed poorly stating that in conflict using "the tactical rules established in the Regulation" was the standard that was to be reached and maintained. ${ }^{142}$ Zaionchkovskii labels this confidence in the regulation as "blind adherence." ${ }^{143}$ He points out several interesting examples of the impact this adherence had on the ability of commanders to come up with any novel solution to problems, citing one where a general began to ask questions beyond the area covered by the regulation regarding troop movements during an exercise. This forced a decree in April of 1844 that stated "infantry battalions do not necessarily have to be in certain places in the lines of battle formations, but will be in direct control of the corps commander."144 This apparently did not satisfy the general, who held the regulations in too high regard to deviate from them or utilize any movements not contained within them. Zaionchkovskii goes on to say that this sad picture was the same for the other elements of the army, having equal effect even on the cavalry, ${ }^{145}$ a force whose major purposes were to possess unusual dexterity and flexibility to take advantage of changes in battle and exploit enemy weaknesses at a moment's notice.

\subsection{Officers Unable to Make Tactical Decisions at Dargo}

An officer present at Dargo, V.A. Gaiman, describes a situation that resulted partially from the attitudes regarding rigidity the of formation discussed above. He focused on what has come to be known as the Sukharnaia Ekspeditsiia or Biscuit Expedition, dispatched on the $10^{\text {th }}$ of July to secure provisions for the main Russian force

\footnotetext{
142 Curtiss, The Russian Army, 115.

143 Zaionchkovskii, Vostochnaia Voŭna, 476.

144 Ibid.

145 Ibid.
} 
which had easily taken Dargo (without inflicting many casualties on Shamil's forces) and was now waiting there. Baddeley states that Vorontsov could have easily pushed on to Gherzel Aul with the five days of provisions his forces had left, seizing the tactical initiative and not using up of the food and supplies, but he chose to stick to his original plan to wait for the resupply convoy. ${ }^{146}$ Gaiman seems to have believed that much of the error of this biscuit expedition was the responsibility of poorly chosen commanders, stating that the General Klugenau, an "undeniably brave and competent general," was a poor choice for command of this excursion as "most of his work was in Dagestan, where there was a specific method of combat" ${ }^{147}$ different from the mountainous and heavily forested area around Dargo. Gaiman describes General Passek as "passionate, capable, beloved by the troops," ${ }^{148}$ contrasting with Baddeley's descriptions of the same man as "impetuous." "149

To secure provisions, Klugenau was to command the main body, General Victorov the rearguard, and General Passek was to lead the advance guard as he had done during the advance on Dargo. An officer in attendance, N. Gorchakov, describes how the expedition was doomed from the start, as recent rain had made their proposed route almost impassable with mud that made the undulating terrain slippery. ${ }^{150}$ Undeterred, Passek took his advance guard quickly forward, storming barricade after barricade. ${ }^{151}$ Another observer, N.I. Delvig, notes that the main body under Klugenau quickly became

\footnotetext{
146 Baddeley, The Russian Conquest of the Caucasus, 396.

147 V. A. Gaiman, "Vospominaniia V. A. Gaĭmana [Memories of V.A. Gaiman]” in Kavkazskiı̆ Sbornik 3 (1879): 371.

148 Ibid.

149 Baddeley, The Russian Conquest of the Caucasus, 389.

150 N. Gorchakov, "Ekspeditsiia v Dargo: Iz Dnevnika Ofitsera Kurinskogo Polka, 1845 [Expedition to Dargo: From the Diary of the Officer of Koureen Regiment, 1845]," Journal Zvezda 6 (1996): 81.

151 Baddeley, The Russian Conquest of the Caucasus, 398.
} 
separated from the vanguard thanks to the "difficulty of clearing the roads, [as] even two felled trees"152 was enough to hold up the troops. The mountaineers took advantage of this, and soon the whole column was split into small pieces, each fighting its own desperate engagement. The troops caught on a section of road were forced to deal with "murderous fire from the enemy's debris [rough fortifications] on both sides." ${ }^{153}$ Gorchakov states that many soldiers "immediately died from well-aimed shots of the enemy; bottlenecked roads were literally cluttered with their bodies," and that despite the best efforts of the rear guard, it "faltered and fell back, leaving it in the hands of [the enemy], among other things, two guns and the coffin of General Foch."154 General Foch, killed in the fighting on the $6^{\text {th }}$ of July, was thrown into a ravine by the mountaineers, a point which is noted in several memoirs dealing with the event. ${ }^{155}$ By this point in time General Victorov, the officer in charge of the rear guard, had also been killed.

To get back to the main body under Vorontsov, General Klugenau made the decision to re-trace the formation's steps back to Dargo, as opposed to continuing on to Gherzel Aul, where Vorontsov's force would eventually go. It is likely he did this because he felt that the explored path would provide a safer route, rather than the unknown one towards Gherzel Aul. The mountaineers seem to have expected this, and the engineers in the vanguard company under General Passek could not disentangle the

152 N.I. Delvig, "Vospominaniia ob Ekspeditsii v Dargo [Memories of the Expedition to Dargo]" Voennyı Sbornik 7 (1864): 16.

${ }^{153}$ Lisitsyna, G.G., "Vospominaniia Neizvestnogo Uchastnika Darginskoĭ Ekspeditsii 1845. Darginskaia Ekspeditsiia 1845 [Memories of an Unknown Participant of the Dargo Expedition, 1845. Expedition to Dargo 1845]" Journal Zvezda 6 (1996): 70.

154 Gorchakov, “Ekspeditsiia v Dargo," 82.

155 Ibid. 
"skillfully bonded"156 tree-based redoubts. Up against a particularly well-constructed fortification along their route, Passek found himself unable to "persuade the bewildered soldiers or resurrect their courage." ${ }^{157}$ Here, at this "length of the road and in the most of the rubble [was] strewn [dead or wounded] soldiers." ${ }^{158}$ Passek, seeing that forward momentum had been lost, ran forward, apparently shouting either 'farewell my friends' ${ }^{159}$ or 'farewell, my brave brigade', and was killed. ${ }^{160}$ Baddeley believes that Passek had actually become separated from his troops within the defensive work, and that it is certainly true that Passek was killed, it is also likely that nobody actually saw the event happen. ${ }^{161}$ Klugenau, unwounded but with clothes apparently riddled with bullets, brought the midsection of the column to this blockage, fought through it, and managed to bring the force back to Dargo. Unfortunately most of the provisions for which the expedition was mounted were lost, along with 2 generals, 17 officers, and 537 enlisted men killed, and just fewer than 1000 wounded. ${ }^{162}$ Vorontsov now had to care for 1000 wounded, whom he would not abandon, and had to make his way through the forest to Gerzel Aul. Baddeley states that he know his only salvation was General Frietag, the commander of the left flank stationed in Grozny, who could aid Vorontsov's force. Messengers were dispatched and Vorontsov's now ponderous force began the march towards Gerzel Aul, and Shamil's forces fought a delaying action in that direction for most of the route.

\footnotetext{
156 Delvig, “Vospominaniia ob Ekspeditsii v Dargo,” 17.

157 Gorchakov, “Ekspeditsiia v Dargo,” 83.

158 Lisitsyna, “Darginskaia Ekspeditsiia 1845,” 72.

159 Delvig, "Vospominania ob Ekspeditsii v Dargo," 17.

160 Gorchakov, "Ekspeditsiia v Dargo," 83.

161 Baddeley, The Russian Conquest of the Caucasus, 401.

162 Ibid., 402-403.
} 
General Klugenau had been vocal about his steadfast belief in Suvorovian ideals such as 'the head doesn't wait for the tail', meaning that it was not necessary to maintain close order in large scale formations. ${ }^{163}$ This is fine in a European setting, where visual communication and thus reaction is possible thanks to the flat terrain, but in the mountains of the Caucasus it meant separating from the rest of the Russian task force. The officers present at the Biscuit Expedition were thoroughly unable to improvise or deviate from a set-piece battle, resulting in chaos and many casualties. It is highly probable that if these men had been allowed to implement adaptive tactics during training, instead of being forced to rely entirely on a codified set of regulations, they may have had a better understanding of how to cope with complex defense offered by the mountaineers. This could have meant avoiding lethal mistakes such as becoming bottlenecked (forced in-between two narrow points), and causing the rear-guard to be pushed backwards onto the formation it was supposed to be protecting. As has been discussed earlier in this work, the British had great success in employing skirmish troops, those able to think for themselves and rapidly move and adapt, in heavily mountainous terrain against a skilled adversary in Nepal in $1814 .{ }^{164}$

\subsection{The Impacts of Regulation on Troop Movements and Formations}

Hard regulations stated that troops were to be in three lines, or in one of five battle formations for infantry and artillery, or one of three or four for cavalry. The lines of three troops were also in three, one group occupying either front, middle or rear

\footnotetext{
163 Delvig, “Vospominaniia ob Ekspeditsii v Dargo,” 15.

164 Kaushik Roy, The British Army in India: From Colonial Warfare to Total War, 1857-1947 (London: Bloomsbury Academic, 2013), 52.
} 
positions. The middle would be in battalion line formation, three hundred paces from the front formations, while the rear was a further three hundred paces to the rear in regimental columns. In the 1840 s, limited and Napoleonic-based change to these regulations took place, wherein permission could be gained for battalions to form companies, a smaller formation for the purposes of sustaining lower losses in the face of overwhelming fire. Cavalry occupied a flanking position to the sides of the battalions of infantry, with batteries of artillery dispersed between. ${ }^{165}$ These were the formations by which their fathers and grandfathers would have fought the forces of Napoleon, formations that occupied vast areas of land and were at the best of times difficult to maneuver with officers of varying caliber. Recall that the Russian military chose to practice these formations every year in grandiose fashion at the same conveniently open and flat locales, for to do otherwise would have been to invite embarrassment in front of senior officers or occasionally the observing Tsar himself. These formations, set in stone in a codified manual of regulations strictly adhered to by all levels of command, would be of little positive effect in a location with anything but flat open terrain.

In reality, the use of these regulations more often than not led to an inappropriate adherence to a parade ground mentality at seemingly inappropriate times and in inappropriate places. Uniformity was a vitally important aspect and part of this attitude, and there were examples of regiments and platoons attempting to make even those aspects of appearance beyond an individual's control subject to uniformity. Hair colour and moustache length (nothing is said of those unable to grow a moustache) are noted as

165 Curtiss, The Russian Army, 114. 
sometimes being influenced by uniformity policies. ${ }^{166}$ Of course, other militaries enforced grooming standards, such as the British during the $18^{\text {th }}$ century, wherein men's hair was to be "tied a little below the upper part of the collar of the coat, and to be ten inches in length," 167 but they began to move away from this during the nineteenth century. They likely saw that it was impediment to their troops, and the above noted British example citing the practice of hair styling was abandoned by the early nineteenth century for the majority of units. Curtiss cites the example of a battle procedure inspection by General Diebitsch of a Caucasian army set to engage Persian forces in 1827. Diebitsch, in his inspection reportage, speaks only and often of things like "the individual posture of the soldiers and the dressing of ranks on parade... a smooth and firm stride... and the elegant fit of the uniforms." 168 This was the case for the infantry, for the cavalry he was apparently more interested in the shape of the horses than the men, and of their riding performance while on the inspection parade. ${ }^{169}$

Curtiss cites more examples of this type of behavior, discussing how the Tsar, when with his army marched against the Turks in 1828, felt it was not just necessary but his military duty to hold a succession of full formal parades followed by large-scale maneuvers in the dead of summer. Curtiss cites a quote by Prince Gorchakov from 1854, over 20 years later, who, after having reviewed his troops posted along the Danube, wrote extensively on the parade ground prowess of his men. He stated "the alignment and formation of [the] troops in the parade march by double companies and in close columns

166 Zaionchkovskii, Vostochnaia Vŏ̌na, 417.

167 The National Archives, London, War Office, W03/19, Infantry and Cavalry to wear their hair Queued, 329.

168 Curtiss, The Russian Army, 113.

169 Ibid., 114. 
were so fine and precise that the men appeared ready for review." ${ }^{170}$ In this case, a review referrers to an inspection by a high-ranking individual. This behavior meant that they were less prepared for the rigors of then modern combat against an asymmetric foe than they would have been for a parade. Indeed, in 1854 Russia's biggest foe came in the form of an alliance between France, Britain and the Ottoman Empire, all enemies who fought on a similar plane, but it seems that in the Crimean context they did so rather better than their Russian counterparts.

The individuals who provided the training were by and large enlisted senior noncommissioned types, the sergeants and corporals. These men had the experience to know what was important, namely, parades. ${ }^{171}$ Thus the emphasis in training was primarily on personal drill, the steps, turns, and weapons drill that needed to be performed accurately and to the correct timings in order to have thousands of men move in concert. Officers and indeed the men hated field training, due in no small part to the fact that it was difficult. ${ }^{172}$

During the final stages of the Dargo expedition, the column began to move towards Gerzul Aul, and it appears that many of the officers held to the maxims contained within the regulations, with groups of Russians repeatedly bounding over obstacles only to become separated and killed by the waiting enemy. ${ }^{173}$ Eventually General Frietag, who had foreseen this very possibility and readied his forces in advance, met with Vorontsov's force near Gerzul Aul. ${ }^{174}$ All told Vorontsov lost 3 Generals, 195

\footnotetext{
170 Curtiss, The Russian Army, 114.

171 Ibid., 118.

172 Ibid., 119.

173 Baddeley, The Russian Conquest of the Caucasus, 405.

174 Ibid., 409.
} 
officers, and 3433 men killed and wounded, along with three guns. Baddeley points out that the Koureen regiment lost 603 men and 23 of its officers out of a full compliment of 850 , and that this regiment had been used as a flanking unit. ${ }^{175}$ It is difficult to see how the Russians had been able to deploy flanking units given the narrowness of their routes and their inability to operate in the undulating terrain, and it seems more likely that the Koureen regiment was in fact used as a frontal unit, or one which advanced directly toward the front of an opposing one, rather than moving to its side.

The parade-ground mentality so ingrained during training proved to be useless at Dargo. Officers and men found themselves incapable of dealing with the varying tactical situation, even committing the same mistakes repeatedly. The exclusive use of closeorder drill during training created an army suited only to tasks on flat, open terrain, where the space to move these cumbersome formations was ample. As Curtiss states, the Russians were unusually good at this, so it is no surprise that they were able to employ these tactics with good effect in Central Asia.

\subsection{Weapons and their Tactical Implementation}

In a modern military, mastery of one's weapon is paramount. Successful historical militaries, at least those within the age of firearms, share this trait. The British are often acknowledged as being historically the most skilled with a muzzle-loading weapon, attempting to maintain a standard wherein men could load, aim and fire their weapons in concert three times per minute. It was this skill that allowed the British troops, who during the Napoleonic Wars fought in two lines allowing a greater frontage

\footnotetext{
175 Baddeley, The Russian Conquest of the Caucasus, 410.
} 
of firepower, to smash densely packed French column formations. These columns were easily able to charge over top most of their opponents by simply absorbing fire, and having men who fell in front replaced by the men behind, until the formation was upon the enemy. However, the effect of disciplined volleys, speedily fired, by the British lines was so violent that it shocked more than one French column into retreat. ${ }^{176}$ The Russian military certainly could not match the speed of the British with a musket. Zaionchkovskii notes that prior to the Crimean War, Russian infantry had a rate of fire with a flintlock musket of "about one round per minute, and then only in good weather." 177 At Dargo, an inability to employ the firepower of their muskets meant that the Russians had to resort to other, less effective tactics, such as simply charging fortified positions with bayonets. ${ }^{178}$

This was due entirely to the abysmal state of Russian musketry training. Speed and accuracy were not only considered unimportant, it appears that very often they were not even judged or noted when rare firing practice did take place, with the predominant concern being that all the men fired their weapons with precise unison. This was meant to increase the volley's shock value, the precursor to a bayonet charge called for by Napoleonic tactics. Like close order drill, it was noted that the men had particular skill at this. ${ }^{179}$ Had this training been done with live ammunition aimed at targets, which it was not, there may have in fact been some benefit to it, as the ability to fire in unison would mean a greater and more violent impact upon an opposing enemy formation, provided the volley hit the formation and did so with some frequency. Muskets were only an

\footnotetext{
176 James R. Arnold, “A Reappraisal of Column versus Line in the Peninsular War,” The Journal Military History 68, no. 2 (2004): 536.

177 Zaionchkovskii, Vostochnaia Voĭna, 427.

178 Dondukov-Korsakov, "Moi Vospominaniia,” 119.

${ }^{179}$ Curtiss, The Russian Army, 121.
} 
effective weapon at less than 100 meters when well maintained, and when fired from concentrated formations. It seems however that generally blank ammunition, that is, ammunition with no missile or bullet, was used and little attention was paid to the direction of the weapons' aim. ${ }^{180}$ This would have never allowed for target practice, and thus the development of marksmanship, as the soldiers would never know if the direction of their weapon was toward a viable target. Curtiss points to an example of a piece of military literature written in 1859 that contained accounts of soldiers with years of service who admitted to never having fired a live cartridge, "as their commanders regarded musketry training as the last item on the agenda, to be dealt with when there was no inspection in prospect and there was nothing else to teach." ${ }^{181}$ With the officers not teaching firearms training, the men learned to regard it as of only very secondary importance to parade matters, and even regarded range practice as a punishment. Even when officers did attempt to adequately train their men in musketry, scarcity of resources for training would stop them, or they would revert back to firing clay rounds or blanks. In 1854 the Ministry of War was forced to order a stoppage to the use of clay rounds, as they destroyed the interior of the musket barrels. ${ }^{182}$

The logic behind this lack of appreciation for marksmanship and weapons drill in general points to the thorough level of the penetration of Suvorovian thought within Russian military theory. General Dragomirov, that keeper of Suvorovian knowledge, espoused the most core tenant of that philosophy by ensuring that training was aimed at the bayonet charge, and that "any exchange of fire was merely a prelude to a climactic

\footnotetext{
180 Curtiss, The Russian Army, 121.

181 Ibid., 122.

182 Ibid., 122-3.
} 
struggle of wills as two opposing forces encountered each other in hand-to-hand combat." 183 The theory behind goes back to tactics learned during the Napoleonic era, wherein the most efficient way to break an opposing enemy line was to incite fear in it through a physical charge, rather than the slow and methodical grinding down of it through the application of firepower. This of course was a more effective tactic or perhaps the only viable one when outmatched by an opponents' rate of fire. Following the punishments Russian soldiers had received at the hands of British and French rifled breach loaders in the Crimea, often at 1000 paces out and dramatically beyond the reach of Russian muskets, Dragomirov warmed to the idea of a more equal emphases on bayonet and bullet. Technology advances would have forced his hand, but in the end he feared that "a preoccupation with aimed rifle fire caused soldiers to become inordinately concerned with marksmanship...that reduced momentum in the attack as soldiers halted to engage targets." 184

In 1866 a new infantry regulation document was published. These documents were and meant as a guide for training and effectively employing soldiers. Even in 1866, within the first new full infantry set of regulation since 1831, "assault formation placed four-fifths emphasis on cold steel and one fifth on firepower." ${ }^{\prime 85}$ After the Caucasus War, where the bayonet had proven itself to be useless against hidden marksmen firing from behind cover, the Russian military establishment still refused to let go its Napoleonic ideas regarding infantry firepower. There was, after this regulation, an enforced strict conservation of ammunition to even skirmishing companies, or those

\footnotetext{
183 Menning, Bayonets Before Bullets, 39.

184 Ibid., 41.

185 Ibid., 42.
} 
marksman set in front of line formations meant to destabilize approaching bodies of troops, allowing them to only use half of their issued battle load of 30 rounds during an attack. If commanders did not allow line infantry companies to reinforce skirmish lines, a respective battalion limited itself to ten percent of its available firepower in an attack. ${ }^{186}$ One must keep in mind that this new regulation was published after the Crimean War, and well after the Caucasus War, but that it actually represented a slight improvement in terms of flexibility (battalions did have the option to reinforce skirmishing companies with line infantry, even if they were loath to do it) and firepower application. This did not bode well for appropriate firepower application in the Caucasus theater, and it is easy to see how the prevailing military thought of the era would have quashed any initiatives taken by lower ranking officers, as Gaiman observes, to train their men to shoot. ${ }^{187}$ The officers at Dargo recognized that it was in fact the mountaineers who were skilled in the implementation of their weapons, and not their own troops.

The Russian military not only disregarded the importance of skilled musketry or firearms handling, they ignored technological advancements, even ones which would have theoretically made the handling of weapons easier. This included technology such as prefabricated cartridges using a breach loading weapon system. The Tsar himself weighed in on this issue early in the nineteenth century, but decided that it was best for Russian troops to stay with traditional armaments. He understood, from a professional perspective, the benefits that might come of a breach loading system (wherein the round and propellant is placed directly in the rear section of the barrel, rather than being forced down from the top), but he immediately implied negative fiscal implications, stating that

\footnotetext{
186 Menning, Bayonets Before Bullets, 42.

187 Gaiman, “Vospominaniia,” 366.
} 
this technology would lead to the overly expedient discharge of ammunition. ${ }^{188}$ This sentiment is highly ironic, given that many military minds of the era would have likely paid almost any price to have the ability to rapidly fire lead bullets and balls at their enemies. It is obvious from the attitude displayed by the Tsar that he adhered strictly to Napoleonic tactics, wherein it was understood that the best way to defeat an enemy was to force the disintegration of their musket line through the application of a hand-to-hand charge. Either that, or he appreciated the state of financial ruin under which his military operated and took every opportunity to save money where he could while simultaneously launching expensive military campaigns. The Tsar was not the only person to espouse this idea. In fact, a fear of running through too many cartridges was common amongst senior officers. Curtiss notes that there were many discussions and academic papers published on this issue, with all of them stating something along the lines of "while these weapons [breach loading rifles] had great value, they could not be given to the infantry, as they would quickly fire off all their cartridges."189 Russian officers clearly did not trust their men to manage a volume of ammunition effectively. Then again, it is hard to see how they could, never having had the opportunity to try. This attitude affected training, wherein there was almost never ammunition for these purposes, and those soldiers who did fire live rounds were made to go and find them, clean them of dirt and prepare them for re-usage. ${ }^{190}$

The weapons the Russian army did have and did use were more often than not maintained at such a low standard that they often failed to work. The parade ground

\footnotetext{
188 Zaionchkovskii, Vostochnaia Vŏ̌na, 31.

189 Curtiss, The Russian Army, 120.

190 Ibid., 121.
} 
mentality meant that weapons were maintained not so they might be effective in battle, but so that they looked spectacular for inspections. An 1838 orders section entitled Harm to the musket from a lack of knowledge of how to treat it, stated that muskets were often systematically abused to the point of ceasing to work at all. ${ }^{191}$ Even those parts that required oiling due to friction during use were neglected. Most astonishingly, muskets were damagingly altered so they sounded better when the soldier holding it performed parade drill. In 1851 the Tsar, illustrating that this was not an isolated issue, attempted to stop to all kinds of strange behavior surrounding soldier's weapons. A ban was placed on the patching of barrels, gluing stocks, and "making various crude alterations to the firing mechanism." ${ }^{192}$ The situation was worse for militia battalions enlisted to fight in the Crimean war, where it was commonplace for upwards of seventy percent of the weapons issued to them to not fire at all. Such was the disregard for the weapons of the infantry for much of the nineteenth century.

V.A. Gaiman, writing in retrospect, opens his work on the subject of Dargo discussing the general shortcomings of the Russians and the advantages of the mountaineers in that region. He describes the mountaineers as "armed with rifled guns that shoot further and more accurately than ours," and as "skillful hands, accustomed to shooting almost from childhood, whereas our soldiers had no time to learn to shoot." ${ }^{193}$ It is possible that the mountaineers did in fact employ rifles, a variant of muzzle-loading weapons with grooves in the barrels to increase accuracy, as the Russians had lost some

191 Curtiss, The Russian Army, 124.

192 Ibid., 124.

193 Gaiman, “Vospominaniia,” 366. 
quantities of these weapons in the region in the years prior to Dargo. ${ }^{194}$ Gaiman writes, "the highlanders were able to skillfully use the terrain and acted in all directions, whereas we also had to move in masses," and that the "highlander is easily dressed, without any burden, and could quickly change place, while our soldiers with heavy combat equipment... often a six-day supply of food, entrenching tools, and had to move slowly." 195 He believed that these factors were "main reasons why we suffer[ed] comparatively enormous losses." 196 Gaiman speaks to many of the issues discussed in this work, but he importantly brings up the lack of marksmanship training undertaken by the Russians. As we have seen, this might be due to a variety of reasons, ranging from the economics of the Russian regimental system, to the inebriation or lack of interest by those responsible for the implementation of training.

The infantry was not the only arm of the military that was subject to impractical guidelines. The problems faced by the infantry were largely the same ones faced by the cavalry, though it can at least be said that they did not have to deal with the inefficiencies of the Russian musket, being primarily a sword or lance wielding force. Cavalry was used at Dargo, but accounts of its use paint a picture of disastrous inefficiency. The following is an examination of the development of Russian cavalry, and an exploration of the issues that the evidence shows had a negative impact on the combat. Cavalry exercises were pre-arranged affairs and commanders had little mind for deviation from regulation or prescribed movements. Interestingly, they almost never studied skills like

\footnotetext{
194 Gammer, Muslim Resistance to the Tsar, 146.

195 Gaiman, "Vospominaniia,” 366-377.

196 Ibid., 377.
} 
scouting or long marches ${ }^{197}$ abilities that were natural to most nation's cavalry and were for that reason emphasized during training so the riders might be particularly skilled during wartime. If the cavalry did not have to deal with the problems of firearms, they did have to deal more so with logistical concerns. A man might carry his own food in the infantry, but this is not possible for a horse, and as such cavalry must rely on adequate logistics. Curtiss talks of several times when these logistics failed completely, devastating cavalry forces. ${ }^{198}$ Discipline, a common feature in the steadfast infantry regiments, who as we have seen, did not retreat even while being subject to staggering losses at Dargo, seems to have been much more lax in cavalry squadrons, and Curtiss points to several occasions where this led directly to combat losses against the Poles and Ottomans. It seems that often Russian cavalry forces were overcome by the mobility offered by their mounts, and set out on unimportant and self prescribed missions to ill effect, as the reader will see shortly. ${ }^{199}$ Oddly, despite this mobility, cavalry units actually moved slower on long marches than dismounted units, for there were strict limitations on speed and enforced rest days at the end of marches. An infantry unit could march from St. Petersburg to Moscow in ten days, while it took a cavalry unit four weeks. ${ }^{200}$ The Tsar, realizing that the cavalry needed some toughing up, organized exercises wherein speed and rapidity of movement were the keys to success. Sadly though, the units were so unprepared and the commanders so uninitiated to these types of

197 Curtiss, The Russian Army, 132.

198 Ibid., 133.

199 Ibid., 134, 135.

200 Ibid., 136. 
movements that it "cost them dearly in dead horses," and in one famous instance, seven hundred..$^{201}$

Again we see units that perform remarkably well in parade ground routine, but which were unprepared for war. The cavalry seems to be unique in that it was unprepared not only for an unconventional conflict in the mountainous Caucasus, where cavalry could have proved particularly useful in scouting or skirmishing, but also for conventional war, as Curtiss' account of them reads like a catalogue of defeat for cavalry units at the hands of the Poles, Ottomans, and in the Crimea against western Europeans. Curtiss also notes the interesting case of the Cossacks, who were likely uniquely able unconventional warriors, but who within their service in the Russian army were treated as the lowest of the low. ${ }^{202}$

As is evident, Russian cavalry of any sort had little training in how to deal with anything other than standard movements on flat, unopposed terrain. This lack of experience in tackling a fortified position in variant terrain shows quite clearly in the account of Dondukov-Korsakov. Having only trained on flat ground with no fortification, he and his comrades made the hasty decision to attack a barricade while still mounted, only to discover that it was too wide to jump in many places. ${ }^{203}$ While attempting to negotiate the defenses, his friend is shot, and eventually DondukovKorsakov is wounded. ${ }^{204}$ While this incident in itself shows a lack of command thinking, the consequences of the actions by the cavalry would prove to be worse. A second hasty attempt to breach the barricade was made to facilitate the survival of the chasseur unit

\footnotetext{
201 Curtiss, The Russian Army, 137.

202 Ibid., 141.

203 Dondukov-Korsakov, “Moi Vospominaniia,” 117.

204 Ibid., 117.
} 
now entangled within it, and two mountain guns were quickly left in the open and unattended in the chaos. Knowing the value of these guns, now devoid of crews to serve them or protect them, a hasty recovery action was attempted by a General Foch, whom Dondukov-Korsakov notes was not in charge of any troops and was one of the "amateurs from headquarters." 205 Foch and his comrades were quickly killed, and DondukovKorsakov recalls that he was lying close enough to see the entire affair. Finally, another element of the advance guard was able to clear the obstructions using bayonets and that combat engineers brought up were able to remove the positions unblocking the way forward for the remaining body of troops. ${ }^{206}$ Baddeley credits Vorontsov himself with ending this action, stating that the general "sent some Georgian militia and dismounted Cossacks into the wood." ${ }^{207}$ Both Dondukov-Korsakov and Baddeley describe the end of this engagement as quick and easy compared to the beginning of it, ${ }^{208}$ which forces one to wonder why this dismounted approach by troops who appear to have been better suited to the terrain than Russian regulars was not used in the first attack. The fact that this was not the case is likely indicative of a lack of coordinated command and control, wherein the cavalry was allowed to act of its own volition rather than in conjunction with any other formations.

The engineers and artillery were in markedly better shape than their counterparts in the infantry and cavalry in terms of their performance in war. It seems that the nature of engineering itself as a trade allowed for this, wherein ingenuity and adaptability are essential to the craft at a very basic level. American Major Richard Delafield, in a report

\footnotetext{
205 Dondukov-Korsakov, “Moi Vospominaniia,” 118.

206 Ibid., 119.

207 Baddeley, The Russian Conquest of the Caucasus, 395.

208 Dondukov-Korsakov, "Moi Vospominaniia," 118.
} 
entitled "On the Art of War in Europe in 1854, 1855, and 1856," stated that within the Crimean War, engineers were never content to simply establish fortifications and leave them, rather they "actively engaged in adding to, and strengthening the existing works." ${ }^{209}$ In the Caucasus, examples of the use of engineers shows that they were not necessarily used in the traditional manner, wherein an engineer unit might be called on to dismantle an enemy blockage prior to an attack. It appears that instead they were used after attacks by infantry and cavalry against these blockages had already failed. When they were used, they performed admirably, destroying enemy fortifications and allowing progress to be made by the infantry. ${ }^{210}$ Unlike within the combat arms, the intellectual study of military engineering was thriving and influential, and even the Tsar espoused an interest that was for once not to the detriment of the craft. $^{211}$

While the engineers performed admirably in combat, maintenance of their fortifications and works established in the Caucasus appears to have suffered terribly. As the number of defensive works in the North Caucasus grew, the quality of some decreased. In the 1830's the Tsar ordered the building of forts along the Black Sea coast, likely as a furtherance of the lines established by Ermolov. One Lieutenant Tornov, inspecting several of these works, calls one a "disorderly pile of mud marking the spot on which should be the breastwork." 212 Describing the situation at a fort called Gagry, Tornov states that "the Cherkessy killed soldiers with muskets within Gagry, [and that] firewood and forage were obtained only by fighting...for months at a time [the soldiers]

\footnotetext{
209 Maj. Richard Delafield, Report on the Art of War in Europe in 1854, 1855, and 1856. From his Notes and Observations Made as a Member of a "Military Commission to the Theater of War in Europe," (Washington, 1860), 36 ${ }^{\text {th }}$ Congress, $1^{\text {st }}$ Senate, Executive Document 59, 35.

210 Dondukov-Korsakov, "Moi Vospominaniia," 119.

211 Curtiss, The Russian Army, 146.

212 Ibid., 158.
} 
fed only on salt meat and bread." ${ }^{213}$ Disease was rampant at many of these forts, and men were constantly dying of fevers and scurvy. ${ }^{214}$ Despite being a better-trained arm of the Russian military, the fortifications of the engineers appear to have had an almost negative impact on the war in the Caucasus.

The artillery, due to an almost totally ineffective infantry firepower model, had to provide the brunt of distance offensive action within the nineteenth century Russian military, and they did not do so poorly in a conventional setting. They were seen to be an elite service, like the engineers. ${ }^{215}$ The Russian Artillery traditionally boasted a high number of guns as compared to other European nations, and was generally seen as being proficient in their use. ${ }^{216}$

Both these elements, the artillery and engineers, appear to have been capable in their crafts. They are, however, combat support elements, and it is impossible to win a war or gain any offensive momentum with only these types of units, which explains why their impact in the Caucasus was unable to reverse the problems created by the unit types of an offensive nature, namely the infantry and cavalry.

Despite bringing approximately 40 guns for the mission at Dargo, it is difficult to see how they might have been effectively employed. Shamil cleverly disengaged the Russians when it became apparent that they might use the guns to attack his fortified position at Andee, ${ }^{217}$ negating their effectiveness as a bombardment weapon. As has

213 Curtiss, The Russian Army, 158.

${ }^{214}$ Ibid.

215 Ibid., 150.

216 Bruce McConachy, "The Roots of Artillery Doctrine: Napoleonic Artillery Tactics Reconsidered," The Journal of Military History 65 (2001): 631.

217 Baddeley, The Russian Conquest of the Caucasus, 389. 
been shown, the terrain was often too steep for men to climb on, ${ }^{218}$ which would render it useless for the purposes of setting up an artillery battery. Indeed, in reading the primary accounts of Dargo, it seems that most of the authors remember the guns as being a hindrance that cost lives to protect, rather than a useful weapon granting a tactical advantage. ${ }^{219}$ And yet, the presence of the guns was one of Napoleonic necessity, and it would have been unthinkable to a traditionally trained Russian officer to abandon them in favour of additional light troops more apt to succeed in mountainous terrain.

\subsection{Dargo Conclusions}

Dargo exemplifies how unprepared the Russians were for combat in the region. A thorough lack of knowledge of how to approach defensive obstacles or to use terrain advantageously led to thousands of casualties in the face of an enemy who understood the Russian lack of capacity for this type of fighting and played to their own strengths. The biggest failure of the mission, the 'Biscuits expedition', should not have happened at all. The force should have had a better understanding of its own logistical capabilities. Had the terrain been flat, it would have been a simple matter to move the logistics train behind the front force, but in the mountains this plan quickly failed, and retrieving provisions in the forested mountains proved to be far more than Vorontsov's officers could handle. Vorontsov, writing to Ermolov after the events, did point out that the 'biscuit expedition' was a failure. ${ }^{220}$ Given the candid nature in which these two officers communicated, this is telling, where an expedition with over 3000 losses and no real accomplishments is not

\footnotetext{
218 Dondukov-Korsakov, “Moi Vospominaniia,” 118.

219 Gorchakov, “Ekspeditsiia v Dargo,” 82.

220 Vorontsov, Letter to A. P. Ermolov, August 1845, 169.
} 
deemed a failure in its entirety. Given the readiness with which Vorontsov admitted his unpreparedness for the mission in pervious letters, it is safe to assume that had he seen the operation as a loss, he would have admitted it to Ermolov. Vorontsov wrote of the successes of the campaign, including how despite repeated breaches created by the mountaineers hindered their progress, these forces always fought back. ${ }^{221}$ This is truly seeing the positive within a negative, given the amount of dead and wounded the mountaineers inflicted upon Vorontsov's troops. This says something about the culture of the Russian military at the time. If such a disastrous event was not regarded as a failure, how then could any change be wrought into the system as a whole?

The Tsar, in his desire for a symbolic victory over the forces of Shamil, organized the mission purely to the end that Shamil would be short one house at its conclusion, and Ermolov points out that Vorontsov would never have been foolish enough to take Dargo of his own initiative. He also points out that Shamil had known that Dargo was strategically unimportant, and that its loss would provide no tangible benefit for either side. ${ }^{222}$ Ermolov shows himself to be a true Caucasus soldier, or one who understands the unique nature of combat in the region, when he asks Vorontsov why he was "avoiding the honor of a skillful retreat that is the hardest against the mountaineers"223 when Vorontsov had gone to some length to convince his peers that the final move from Dargo to the Gerzel Aul was in fact an attack. It is likely that it would have been unconceivable for Vorontsov to think in terms of an honorific retreat. In line warfare, the type Vorontsov and his officers knew, retreat was not only dishonorable, it could be disastrous, as it

\footnotetext{
221 Vorontsov, Letter to A. P. Ermolov, August 1845, 169.

222 Ermolov, Letter to M. S. Vorontsov, August 1845, 172.

223 Ibid., 173.
} 
would have invited a bayonet charge or cavalry pursuit from an enemy. Ermolov stated in his letters that he understood that in the mountains, retreat was necessary for survival. ${ }^{224}$ Despite his failings in the region, Ermolov, a soldier with more experience in Caucasus combat than most, maintained an understanding of the region quite unlike even the most senior and well regarded Russian soldiers of the era. Russian military thinking would simply remain as it had always been after Dargo, ignoring lessons learned in blood. This expedition was carried out after the even more disastrous affair led by General Grabbe in 1842, which itself shows this lack of willingness to learn from past mistakes. Those officers who were present at Dargo questioned the logic behind the mission in retrospect, ${ }^{225}$ but it would take another 15 years of fighting in similar style before the war in the Caucasus could be said to be over.

${ }^{224}$ Ermolov, Letter to M. S. Vorontsov, August 1845, 173.

225 Gorchakov, "Ekspeiditisiia v Dargo," 85. 


\section{Chapter 4: Central Asia and the effective application of Napoleonic tactics}

\subsection{Introduction}

In Central Asia, an entirely different form of combat awaited the Russians. While it had taken over half a century to conquer the Caucasus, with war there continuing like an open wound, combat in Central Asia presented specifically the types of issues that the Russians always traditionally excelled at understanding. Having learned little from the Caucasus did not impact Tsarist performance in Central Asia, as that theater offered up challenges more similar to those encountered in the euro-centric Napoleonic type of battlefield the Russians refused to forget. The Russians did make some adaptations that proved to effective, such as the use of camels to enable the carrying of substantial logistics in the desert, and by the 1870s the Russian military had begun to update some of its weapons technology. However, the importance of Napoleonic tactics in the Central Asian theater remained. The reader will see that adaptations made by the Russians in Central Asia served to enable them to further exercise their preferred method of warfare, that of the Napoleonic era. It would be wrong to state that there were not other factors at play in Central Asia, such as geopolitical situation in the area, and issues within the militaries of the various Central Asian states in the nineteenth century, and these will be discussed. In the end, however, Central Asian states fell under Russian rule through the application of a Russian military force that relied heavily on its Napoleonic ideals.

This chapter will present evidence that shows that the Tsarist military was successful in Central Asia thanks largely to the application of same system that had caused so many problems in the Caucasus. This chapter is structured so as to make direct 
comparisons with the battle at Dargo and the Caucasus War, based on a narrative framework of the Russian campaign against Khiva in 1873.

\subsection{Diplomacy and Intelligence in Central Asia}

With the northern nomadic tribes of the steppes of modern Kazakhstan conquered over a longer period of time, the Russians had a firm base from which to rapidly subjugate the more sedentary societies within lower Central Asia. ${ }^{226}$ To that effect, extensive reconnaissance and diplomatic initiatives were started. N. P Ignatiev, a military officer serving in the Russian diplomatic corps, was dispatched to the Central Asian region in 1858. With Shamil captured in 1859, and the Crimean War concluded, albeit unsuccessfully for the Russians, Central Asia was quickly becoming a priority. Ignatiev himself shed some light as to why. He stated: "Asia was the only area remaining for our trade activities and development of our industry because we were too weak to enter into successful competition with Great Britian, France, Belgium and the United States of America."227 Ignatiev even fancied that he helped to form Russia's strategy for the region, as "Asiatics react only to material force and that diplomatic discussions rarely bring positive results," suggesting that naval ships be granted to use the Amu Darya river. $^{228}$

Even on his 'diplomatic' mission, Ignatiev was able to enact the type of policies that would see the Russians through the whole of their conquest, utilizing threats backed

\footnotetext{
226 Robert F. Baumann, "Russian-Soviet Unconventional Wars in the Caucasus, Central Asia, and Afghanistan," Leavenworth Papers: Combat Studies Institute, US Army Command and General Staff College 20 (1993): 52.

227 N. P. Ignatiev, Mission of N.P Ignatiev to Khiva and Bukhara in 1858, trans. John L. Evans (Newtonvill, MA: Oriental Research Partners, 1984), 30. 228 Ibid.
} 
up by military force. More often than not, as far as Ignatiev accounted, these threats had the desired result. ${ }^{229}$ Ignatiev's opinion of Central Asian figures continues to drop, and he eventually wrote to his father stating that "it is demeaning and stupid to force a Russian representative to speak with such scoundrels as the Khiv[ans] and to even consider them equal to us."230 The Khivans would reject many of the Tsar's proposals as delivered by Ignatiev, much to his exasperation. The Khivans, according to Ignatiev, "in spite of their weakness in comparison with the greatness of Russia... did not see the need to make concessions" and "that they absolutely believed in their inaccessibility," ${ }^{, 231}$ meaning their being situated in remote and harsh desert terrain. Clearly, Ignatiev thought little of the position of the Central Asians. Compare this to mentions of the mountaineers in the Caucasus, referred to as skilled men who train from birth to be warriors, ${ }^{232}$ with Ignatiev's commentary. Perhaps decades of war with the inhabitants of the Caucasus forced a weary respect by the Russians, and their ability to sometimes bully the Central Asian khanates politically eroded any military fears.

Ignatiev felt little need to be cautious in his presentation of assessment of the Central Asians, even though Russia had only recently been disengaged in the Caucasus and more recently had lost the Crimean War. This may speak to a Russian inability to remember the lessons of warfare, and a lack of solidified history keeping at this time, though the Russians did have more recent successes in the region. Ignatiev would leave Khiva feeling that the expiditon had been a waste of time diplomatically, as the Khivans

\footnotetext{
${ }^{229}$ Ignatiev, Mission to Khiva, 74.

230 Ibid., 85.

231 Ibid.

232 V. A. Gaiman, "Vospominaniia V. A. Gaĭman [Memories of V.A. Gaiman]” in Kavkazskĭ Sbornik 3 (1879), 336.
} 
did not "appreciate the sending to them of a Russian agent," 233 implying that they had been lucky to receive such treatment. Ignatiev seems resolute that the only way Russia would be able to exercise control over the region would be through the use of force.

The Russians would employ diplomacy in their conquest of Central Asia, as discussed briefly in chapter two, but the brunt of the work would be of a military nature. In the Caucasus, Shamil's uniting of the mountaineers rendered diplomacy largely inert. In Central Asia, the Russians attempted to gain concessions using a soft power approach, such as economic treaties and economic influence activities prior to resorting to violence. Thanks to the divided political geography of the region, and their ability to control allegiances therein, the Russians were able to ensure they never fought a fully united Central Asian military force..$^{234}$

\subsection{Overcoming Logistics and Nature in Central Asia}

In the Caucasus, the mountaineers and nature conspired to make Russia's time there as difficult as possible. Worse, the locals knew how to employ nature against them, and were able to do so to great effect. In Central Asia, the formula was somewhat different. Here, nature would be the primary foe. The Russian's enemies were comparatively unskilled to their Caucasus counterparts, ${ }^{235}$ but this was due to a major disadvantage. The geographic features of a battlefield, or "the sum total of its physical attributes, is of greatest significance in helping determine the outcome of battle."236 In the Caucasus, the mountaineers had every advantage in terrain. Hilly or slopped terrain is known by

\footnotetext{
233 Ignatiev, Mission to Khiva, 95.

234 Baumann, “Russian-Soviet Unconventional Wars," 52.

235 Ibid.

236 P. Doyle et al, Fields of Battle: Terrain in Military History (New York: Springer, 2002), 3.
} 
military thinkers to be the most difficult to traverse, even outside of combat conditions. ${ }^{237}$ The mountains of their homeland provided them with a natural system of fortifications, the use of which they were able to become very proficient. The troops of the Central Asian khanates were never able to use terrain to their advantage as the Caucasus mountaineers had. Rather, they had no terrain that would have granted them any such advantage, at least not in combat, and were not able to match the Russians on the field. ${ }^{238}$ Governor General Kaufman's columns, en route to Khiva as part of the operation to bring that region under Russian rule, did encounter difficulties offered by the unique terrain. Multiple observers mention the fact that Khiva felt it was beyond Russian power, thanks to its being surrounded by deserts on all four sides. ${ }^{239}$ Unlike the mountains, it seems as though the Russians maintained a healthy respect for the deserts of Central Asia, at least in terms of the logistics problems it offered. Many officers present wrote of their extensive logistical preparations, ensuring they had adequate pack-animals, and usually also ensuring they had a number of locally engaged guides. ${ }^{240}$ Once a commander had overcome the dangers of the Khivan desert, such as heat and a lack of water, he could rest easy knowing the most difficult part was over, as the flat, open ground allowed for the specific types of Napoleonic movements at which he had been trained. The specific problems that Kaufman's columns encountered thanks to the Khivan terrain are explored

\footnotetext{
237 Doyle, Fields of Battle, 161.

238 Baumann, "Russian-Soviet Unconventional Wars,” 60.

239 I. A. Maksheev, Istoricheskĭ Obzor Turkestana [Historical Review of Turkestan], (St Petersburg, 1890), 313.

240 D. G. Kolokoltsov, “Dzhizak do Khivy, Pokhodnyı̌ Dnevnik Polkovnika Kolokol’tsova: Ekspeditsiia v Khivu v 1873 Godu [Dzhizak to Khiva: Field Diary of Colonel Kolokoltsov: Expedition to Khiva in 1873]," Voennyı̆ Sbornik 8 (1873).
} 
in the following section, where it will become evident that Russian officers in that operation were more able to cope with flat, unbroken terrain.

\subsection{Khivan Campaign Background}

The conquest of Khiva takes a central position chronologically in the later campaigns to subdue Central Asia. In 1865, Chernaiev took Tashkent, which caused ripples throughout the whole region. K. P. Kaufman was made Governor General of the newly minted Tsarist province of Turkestan, with Tashkent as its capital. With a firm foothold in the region, the stage was set for the eventual conquest of Central Asia. By 1870, Minister of War D. A. Miliutin was voicing his opinion that "a campaign against Khiva was inevitable,"241 likely considering a strategy which involved pushing Russian influence to the Afghan frontier. Militarily the Russians had achieved much for very little in the way of casualties, taking one of the most important cities in the region and establishing a Russian government for less than 2000 dead or wounded. ${ }^{242}$

Reconnaissance efforts by the Russians at Krasnovodsk, on the Khivan side of the Caspian, caused alarm within the Khivan state, and strongly worded letters rejecting each other's claims were exchanged between both sides in $1871-2 .^{243}$ Miliutin, in his capacity of Minister of War, backed a Khivan campaign plan. Even while diplomacy resulted in a delay of these plans, reconnaissance efforts continued. In 1871 reconnaissance missions

\footnotetext{
241 Kolokoltsov, "Dzhizak do Khivy," 62.

242 Ibid., 59.

243 Seymour Becker, Russia's Protectorates in Central Asia: 1865-1924 (New York: Routledge, 2004), 54.
} 
emanating from Krasnovodsk and Khiva's eastern borders reached deep into Khivan territory, destroying "Khiva's faith in the efficacy of her natural ramparts."244

The Khivan campaign of 1873 and its course provide an excellent example of typical Central Asian combat as encountered by the Russians. Organized by Governor General Kaufman, the blow against Khiva was meant to be definitive, on a scale not generally seen in the Caucasus conflict until after the end of the Crimean War. Kaufman, who had overall command of the operation, used all the strategic assets at his disposal, employing formations emanating from the Caucasus (ferried across the Caspian), Orenburg and Turkestan. ${ }^{245}$ Kaufman's column would depart from Tashkent and travel west towards Khiva, while the other columns approached from their respective origins. He stated a desire to command himself, rather than delegate command to a regional authority such as the now relatively peaceful Caucasus Military District. ${ }^{246}$ Kaufman's plans involved the dispatch of five separate columns, from Dzhizak, Kazalin, Orenburg, Mangyshlak and Krasnovodsk, for a total of 13100 men. In addition to these troops, over 22000 camels were brought. ${ }^{247}$ I. A. Maksheev, writing in 1890, describes how Kaufman's plans required the separate columns to all arrive simultaneously at Khiva, though he notes that this in turn required the columns to leave at different times, with no means of communicating with each other. ${ }^{248}$ So, with the broad objective of the city of Khiva set, Kaufman's columns individually began to cross the deserts in the spring of 1873.

\footnotetext{
244 Becker, Russia's Protectorates, 55.

245 Ibid., 63.

246 Ibid., 64.

247 Maksheev, Istoricheskĭ Obzor Turkestana, 315.

248 Ibid., 314.
} 


\subsection{The Effective Application of Napoleonic Scale Forces and Logistics in Khiva}

J. A. MacGahan, an American correspondent shadowing Kaufman, wrote of the preparations for the expedition undertaken by the column under Kaufman's personal command. He observed that Kaufman, understanding the logistical gravity of the task at hand, hired up to 4000 camels for his column, outnumbering the men present. ${ }^{249}$ The use of camels is itself an adaptive technique, as the Russians were aware that horses would have been unable to carry such loads in such a climate with a scarcity of water. It should be noted though that this use of camels also represents a re-iteration of Napoleonic logistics, which were required by the enormous force Kaufman felt he had to employ in his operation. MacGahan also notes that the column was equipped with modern breach loading artillery, along with mountain guns and rockets. ${ }^{250}$ This is a significant artillery compliment, likely consisting of $10-14$ guns and 5 rocket-launching devices, ${ }^{251}$ the likes of which had not been seen on expeditions of similar scale in the Caucasus. The expedition to Dargo in the Caucasus War, an operation of 18,000 men, brought with it 18 guns, a far smaller ratio. ${ }^{252}$ The whole of the Khivan operation had 56 guns for 13,000 men. ${ }^{253}$ Moving guns throughout mountain ranges proved to be overly difficult, and it appears that only the bare necessity of artillery was taken on operations in the Caucasus. The deserts of Central Asia, while representing challenges on their own, made for far easier transport of logistics and firepower, allowing the Russians to utilize a more European-centric version of warfare focusing overwhelming firepower. It should also be

249 J. A. MacGahan, Campaigning on the Oxus and the Fall of Khiva (New York: Harper \& Brothers Publishers, 1874), 163.

250 MacGahan, Campaigning on the Oxus, 163.

251 Ibid., 163.

252 John F. Baddeley, The Russian Conquest of the Caucasus (New York: 1969, Russell \& Russell), 387.

253 Baumann, "Russian-Soviet Unconventional Wars," 65. 
noted that many of these artillery pieces were of the rifled variant,${ }^{254}$ which was the most modern type available at the time and a significant improvement over unrifled artillery. While there were not new rifles for the infantry, this new artillery would prove to be effective in Central Asia. Four thousand camels would make for easier transport of food and other essentials. The inability to effectively transport food on the Dargo operation turned out to be disastrous, and we have seen, the Russians suffered the bulk of their casualties simply attempting to attend to this need. Moving logistics trains utilizing a Napoleonic framework works on flat ground, and this certainly would have applied in Central Asia. There, they would be able to use a system of logistics at which they had trained for decades, rather than be forced to try to adapt a system to mountainous terrain.

MacGahan notes that there was some suffering in Kaufman's column while it was en route to Khiva from Tashkent, stating that in early April they encountered unseasonably cold weather, and that "the sufferings of the troops during this time were extreme."255 A similar event happened during the Dargo operation, when Passek had taken his advance guard too far forward and became isolated when the weather turned foul. In the case of Passek, the real disaster came about as he allowed his section, unable to support itself logistically, to become separated from the main body. The weather was an unfortunate circumstance that made the situation worse. It should be remembered that on this occasion, however, 500 horses died as a result, whereas MacGahan does not note any deaths in the Kaufman column from cold. ${ }^{256}$ Heat on the other hand did cause some issues, and MacGahan notes the deaths of some camels, and that many could not carry

\footnotetext{
254 N. Roerich, Letter to his Father, April 5, 1873, in Dokumenty Russkoi Istorii 4, no. 58 (2002): 18. 255 MacGahan, Campaigning on the Oxus, 164.

256 Baddeley, The Russian Conquest of the Caucasus, 389.
} 
their initially allocated 600 pounds ${ }^{257}$. These trials were overcome on the journey, and did not impose a significant problem to the operation as a whole.

A decision was made by Kaufman to join the column travelling from Kazalin in the same direction as his, which meant deviation from the prescribed route. MacGahan notes that Kaufman decided to do this as he felt his singular column was too weak to encounter the enemy alone, but he also notes that "the result proved that this opinion was wrong." 258 Kaufman's column would now have endure a route with significantly less known water along it, the lynch pin for a desert operation. By the $17^{\text {th }}$ of May the column was in serious trouble, and the need to find water became dire. Native guides were dispatched, and either through luck or through the ability to pick worthy and efficient guides, one returned with a sample of water and the column marched towards it. Water was one problem the Caucasus armies did not seem to encounter, likely due to an abundance of mountain streams in that theater.

Col. Saranchov, within the column marching south towards Khiva from Orenburg, also described the extreme nature of the heat they encountered. Near the end of April, Saranchov noted that the temperature was reaching 29 degrees, and that when combined with the wind and sandstorms that occurred, the progress of the column was difficult. $^{259}$ Due to a lack of available water, the column chose to make difficult moves at night, when temperatures were lower and it was possible to exert the extra energy required to move baggage and supplies across "the drifts of white sand, like a wind-

\footnotetext{
257 MacGahan, Campaigning on the Oxus, 166, 171.

258 Ibid., 165.

259 E. S. Saranchov, Khivinskaia Ekspeditsiia 1873 Goda: Zapiski Ochevidtsa Sapera E. Saranchova [Khivan Expedition in 1873: Notes of the Eyewitness Saper E. Saranchov] (Saint Petersburg: Typ. F Sushchinskii, 1874), 108.
} 
blown snow." ${ }^{260}$ In early May, the column encountered a situation remarkably similar to one encountered by the Kaufman column. Out of water, the column was lucky to have a Kyrgyz guide who claimed to know the location of wells near the columns position. These wells proved to be undrinkable, so the logistics train was dispatched to collect water from their previous wells. ${ }^{261}$ The column would survive this episode and reach its destination.

\subsection{The Effective Application of Napoleonic Firepower Against the Khivans}

Within Kaumfan's group, the search for water led to that column's first real encounter with their Khivan enemy during the operation. A contingent of camels had been sent back from the newly discovered wells of the $17^{\text {th }}$ of May, with escort, to drink and store more water. The water at that location was apparently insufficient to sustain both man and beast simultaneously. The Khivans gained intelligence regarding this move, and set out to attack the small detachment. This attack, conducted "with considerable spirit and vigor," ${ }^{, 262}$ would fail. MacGahan notes that there was not much the Khivans could do against the breech loading weapons used by the Russians. ${ }^{263}$ This situation is both typical of the Central Asian campaigns, and the precise opposite of so many Caucasus War engagements, where the Russians were shot at from well-defended positions by skilled marksmen, and were more often than not unable to return fire until a significant and dangerous reduction in range was made.

\footnotetext{
260 Saranchov, Khivinskaia Ekspeditsiia, 109.

261 Ibid., 110-114.

262 MacGahan, Campaigning on the Oxus, 169.

263 Ibid., 169.
} 
By the time of the Khivan engagement, the Russians had adopted more technologically sophisticated weaponry, replacing the inaccurate muskets in use for most of the Caucasus War. The punishment the Russians had received at the hands of French and English rifles in the Crimean War are probably what finally allowed their use by Russian infantry units. Breech loading rifles are faster to re-load, as a pre-fabricated cartridge fits in the back of weapon, allowing it to be held while working it, as opposed to a musket which must be placed end on end to push the ammunition down the muzzle. Additionally, a rifled barrel enables the round to gain a spin while it travels down the weapon, granting it far greater range and ballistic power than a musket might have. It appears that the use of the rifle was one of the only significant changes to come out of the Crimean War which may have had an impact on the Central Asian campaigns. While technological advances are important, what was likely more vital to the Russians was their ability to employ all of this on flat ground with easy lines of fire and movement. Khivan riders would likely have had little to no cover to advance against Russian forces. D. A. Kolokoltsov, with Kaufman's column, wrote of an incident on 7 May, when enemy cavalry attacked elements of his column while they were attending to wells. He describes how the horsemen were unable to get close enough to properly engage the Russians, as when the horsemen attempted to rush towards the Russian position, they were repelled by Russian rifle fire. As the horsemen continued to make attempts to charge the Russian position, Kolokoltsov describes how the Russian rocket-artillery was able to dissuade them with only three rockets. In the end, Cossack cavalry was dispatched to see the enemy off, and was able to capture several prisoners. ${ }^{264}$ The Khivan horsemen had no

${ }^{264}$ Kolokoltsov, “Dzhizak do Khivy,” 34. 
terrain to cover their approach, shield themselves from Russian fire, and had nowhere to escape when they attempted to retreat. In essence, the only tactic these men had that was of any viability was to hope that their charge towards the Russians would make it all the way. Much of the evidence reviewed herein indicates that they were almost never able to get that far before succumbing to Russian firepower on the open plain. Russian drill, based on Napoleonic ideals, enabled them to distribute overwhelming firepower on flat open terrain, something they had been totally unable to do within the mountains of the Caucasus.

The first encounter with the enemy had proven to be of little concern, but Kaufman's column continued to confront the heat of the desert. MacGahan states that it was the discipline of the Russian soldiers which allowed for Kaufman's column to reach the Oxus river. Some supplies were jettisoned in order to lighten the load of the camels, with two companies left behind to protect these logistics. ${ }^{265}$ The final phase of the march to the bank of the river is noted to have had to deal with only light resistance from Khivan Turcomans, who were kept at bay by the effective use of a screening line of skirmish troops, a key Napoleonic tactic made to work once again in Central Asia. Once the river had been reached, Kaufman ordered the attack of a group of these same Turcoman horsemen, using artillery to break apart their formations and charging the remnant with his own cavalry. ${ }^{266}$ Once again we see that in combat, the Russians were thoroughly in their topographic and tactical element against the Khivans. Able to easily and effectively deploy all the arms available to him in tandem, Kaufman was suffering

\footnotetext{
265 MacGahan, Campaigning on the Oxus, 171.
}

266 Ibid., 172. 
none of the issues that so plagued his Caucasus War counterparts, who at the best of times could only deploy one element to any effect.

The Khivans, searching for any way to gain the tactical upper hand on the Russians, were often inventive in the methods they pursued. Kolokoltsov described the events of 11 May, when the Khivans attempted a ruse to fool the Russians into thinking their number was far greater than it actually was. This was attempted by the lighting of a multitude of fires at night, more so than would have been necessary for the Khivans to do their nightly cooking or camping. ${ }^{267}$ Kolokoltsov states that the Russians did see the fires, and had they been fooled, this incident would represent a tactic which actually took advantage of the flat, sighting-enabling ground. Kolokoltsov states that the camp commander, having observed the fires, ensured the Russian camp was set up properly and promptly went to the $1^{\text {st }}$ Rifle Company and ordered an attack. ${ }^{268}$ Kolokoltsov does not describe the result of the attack, simply moving on to a description of the column moving away from that position, so it is probably safe to say this incident ended in favour of the Russians.

Kolokoltsov's description of the movement of his column on 11 May contains further evidence regarding the success of Napoleonic tactics against the Khivans. He describes the column moving out as being totally covered by skirmishers or artillery on all sides. When advancing, the column would deploy a line of additional skirmishers to the front of the formation, precisely as Napoleonic doctrine would dictate. This proved to be effective, as the Khivans made attempts to attack the skirmish lines, which appeared comparatively weaker than the column behind it. It seems that the Khivans either

\footnotetext{
267 Kolokoltsov, “Dzhizak do Khivy,” 41.

268 Ibid.
} 
became disorganized, or intentionally feinted around the skirmisher line and attacked the main body of the column each time this happened. Kolokoltsov states that, even though he found the war cry shouted by the charging Khivan horsemen frightening, they were "swept away" by the cyclical platoon fire of the sub-units within the column each time this occurred. ${ }^{269}$

The displayed mastery of platoon fire means that the Russians would probably have fared equally well in many of their Central Asian engagements even with musket technology. Open terrain allowed for easy marksmanship, and their enemy was forced to ride close to Russian formations if they desired to inflict any real damage. As Kolokoltsov's and Kaufman's column advanced, they also employed artillery against the Khivan forces to great effect. At a moment when the Khivans allowed themselves to be grouped in a larger body, Kolokoltsov describes how the Russian gunners utilized canister rounds against this vulnerable target. Canister shot is essentially a can full of gunpowder and musket balls inserted into a cannon and fired from its end, generating a shotgun like ballistic pattern, and was generally only used at close range for its devastating effects. Kolokoltsov states that after the Russian guns fired, the area where the Khivans had been present erupted in "clouds of dust and sand, hiding us from [view of] the enemy." ${ }^{270}$ When the dust had settled, Kolokoltsov observed that the enemy had gone, which is likely a euphemism for the enemy having been killed. While this was occurring Kolokoltsov observed that Kaufman was patrolling the various detachments, thanking them for their excellent work..$^{271}$

\footnotetext{
269 Kolokoltsov, "Dzhizak do Khivy," 42.

270 Ibid., 44.

271 Ibid.
} 
Col. Saranchov considered the reasons behind the Russian's ease in combat against the Khivans. He states that despite almost constant skirmishing in the later stages of his column's advance into Khiva, its progress was rarely slowed. ${ }^{272}$ He wrote that the enemy primarily "consisted of riders who, like the rest of cavalry generally, [were] able to operate successfully only on level ground." ${ }^{273}$ This in itself was not necessarily a problem for the Khivans, except that it allowed for the easier training of Russian weapons on to them. The Khivan fear of the column's artillery and longer range breach-loading weapons forced them to give up the use of the only terrain available and to stay out of range of the Russian's weapons systems. When large enough groups of these roaming groups of irregular or non-uniformed cavalry did form to attack the column, Saranchov notes that they were often dispersed easily enough by two or three well-placed rounds of artillery. $^{274}$

A significant engagement took place between the newly joined Caucasus Column and Orenburg columns on the $15^{\text {th }}$ of May. Six thousand Khivans met the now single column, but Saranchov describes their initial movements as "extremely hesitant." 275 This was in spite of the fact that the Khivans outnumbered their Russian foe. It appears that in their previous engagements with the Russians the Khivans were cautious about moving within range of Russian firepower, which is hardly surprising. The remainder of Saranchov's description of the engagement is an almost rambling affair, and seems to indicate that the progress of the battle was difficult to track. This is likely due to the fact that the Khivans would not commit to truly joining battle, but Baumann notes in his work

\footnotetext{
272 Saranchov, Khivinskaia Ekspeditsiia, 118.

273 Ibid.

274 Ibid.

275 Ibid., 127.
} 
that the Khivan force suffered heavy losses, while the Russian casualties totaled only $17 .^{276}$

Firepower, and the ability to use it on flat, open terrain, afforded the Russians their remarkable success in Khiva. In the Caucasus, delaying actions fought by the mountaineers costs thousands of Russian lives, as they were unable to respond effectively to enemies behind cover in broken and hilly terrain. Artillery features heavily in the accounts of the Khivan expedition, artillery that was easily deployed and apparently skillfully used. The Khivans became wary of its long-range impact such that even when they outnumbered the Russians they refused to be joined in direct combat. Had they done so, it seems likely that the affair would have gone even more in favour of the Russians. Artillery and infantry provided the bulk of the firepower in Khivan battles, but other options existed and the Russians took advantage of them when the opportunities arose. Cavalry, almost totally unusable in the traditional sense as shock troops or for turning a flank in the Caucasus, proved to be an effective tool on the plains of Khiva. Saranchov wrote of how as soon as appropriate terrain was reached in the battle against the large Khivan force of 6000 , Russian cavalry deployed and was able to pursue the enemy. ${ }^{277}$ It would be a stretch to state that this shows that officers in this theater were better trained for multi-arms operations (operations using artillery, infantry and cavalry in conjunction with one another) as no distinct proof of this could be found. What is likely is that the flat, open terrain simply made for far easier command and control than had been available in the broken and mountainous terrain of the Caucasus. However, it can be stated that some command figure apparently recognized that the progress of the

\footnotetext{
276 Saranchov, Khivinskaia Ekspeditsiia, 127.

277 Ibid.
} 
engagement had reached a point favoring a cavalry deployment, and a decision to do this was made. Officers in the Caucasus had significantly less opportunity to see possible uses for cavalry formations, though it does not speak well to their tactical skill that cavalry was on occasion used against defensive positions in mountainous terrain. ${ }^{278}$

The day following the engagement of the large Khivan force, another running battle occurred. It seems that the Russians were able to apply a key Napoleonic tactic in this running engagement, deploying horse-artillery ${ }^{279}$ and infantry in combination to drive the enemy backward while inflicting casualties. ${ }^{280}$ When the Khivans attempted to reverse the momentum and went on the offensive, they were stopped in their front by accurate fire from Russian skirmish lines, and forced to retreat by artillery engaging their flanks. ${ }^{281}$

Where the Khivans employed their own limited artillery, the Russians took advantage of the greater range of the weapons used by their infantry, picking off Khivan gunners. This in turn allowed Russian artillery to move into positions more suited to counter battery fire. ${ }^{282}$

The engagement described by Saranchov was the last significant engagement during the Khivan campaign. Kolokoltsov, discussing events on the $28^{\text {th }}$ of May, detailed how it had become apparent that there would be go great final attack against the city of Khiva proper, and that this was a disappointment to the troops. After an intensely hot 30

\footnotetext{
278 A. M. Dondukov-Korsakov, “Moi Vospominaniia [My Memories],” in Starina i Novizna: Istoricheskil Sbornik, Book 6 (Saint Petersburg: Tipographiia M Stasiulevicha, 1908), 117.

279 Horse artillery units are small, light guns pulled by teams of horses. The gunners ride the horses or are perched on the gun carriage. They excel at providing rapidly deployable firepower in the appropriate terrain.

${ }^{280}$ Saranchov, Khivinskaia Ekspeditsiia, 141.

281 Ibid.

282 Ibid., 153.
} 
verst (just over 30km) traverse placing Kolokoltov's column 16 miles from Khiva, word arrived that the Khvians would not fight. ${ }^{283}$

\subsection{Khiva and Central Asian Conclusions}

Saranchov, unusually for a contemporary Russian observer, gives the Khivans some credit for their actions, stating that they "acted deliberately and quite aggressively." ${ }^{284}$ Despite their deliberation, the Khivans were simply no match for the Russians. Superior firepower, organization and tactical ability allowed the Russians to dominate the entire affair. The Russians were able to overcome the natural obstacles, and were subsequently able to use the full measure of their Napoleonic tactics and operational strategy. The officers and men of the Kaufman expedition were truly in their element in Khiva, leading and fighting as they had been taught for their whole careers by a system that refused to deviate from approved doctrine. Technological advancements only further enabled Russian dominance, and acted as a force multiplier without demanding a change in tactics. Khiva was defeated quickly and effectively. Baumann describes the end of the campaign, stating that the "khan, recognizing the inevitable, sent an emissary offering to surrender. ${ }^{285}$ He calls the expedition proof of "the power of Russia to project its military strength throughout the region." 286

\footnotetext{
283 Kolokoltsov, "Dzhizak do Khivy," 68.

284 Ibid., 149.

285 Baumann, "Russian-Soviet Unconventional Wars," 68.

286 Ibid., 68.
} 


\section{Chapter 5: Conclusion}

The Russian military of the nineteenth century was thought to have been one of the most powerful in existence at that time. The size of their military allowed the Russians to exist on the same level as other great powers of the era, and it was this military that enabled such a rapid and vast territorial expansion by that state, covering much of Eurasia. The key role Russia played in defeating Napoleon established a mentality within Russian political and military minds wherein no power could overcome them. The French military in that war was unfathomably large and powerful, and yet Russian military strength was able to defeat it. From this perspective, it is not difficult to see how the tactics and strategy which beat that military became such an overwhelmingly central part of Russian military thinking for the next hundred years.

Napoleonic military philosophies and techniques permeated every aspect of the Russian military, impacting its education systems, structure, training, manning, and the tactics and weapons it employed. These philosophies and techniques caused a stagnation resulting in decades of war necessitating change being ignored by those powerful enough to enact policy in overtly conservative organization. Officers going to fight in the mountains of the Caucasus read about war in Europe, rather than works on the conditions of their future theaters. Those officer's instructors would have been encouraged to continue to research and teach the same Napoleonic principles that had been in place for decades. Training was aimed at creating an army that could march in disciplined fashion over flat terrain towards their enemy, deliver one expertly-timed volley, and drive forward with a bayonet charge designed to cause the opposing enemy line to break and retreat. This training in turn impacted the tactics employed by the men and their officers, 
and the intellectual stagnation that allowed for the continuation of that training enabled the rejection of modern weapons far beyond what should have been allowed.

What is particularly interesting is how this stagnation was allowed to continue even while Russia was engaged in conflicts that flouted Napoleonic norms. Russian commanders continuously tried to engage Shamil and his mountaineers according to Napoleonic principles, while their enemy learned how to better use the advantages the terrain of their homeland afforded them. The campaign led by General Vorontsov to Dargo is an example of how the Napoleonic system failed every element of the Russian military. It left them uniquely unprepared for combat there, even while other nations developed the ability to adapt their fighting techniques to varied topographical and social terrains. Russian officers in the mountains of the Caucasus simply had no training to deal with the terrain, and no concept of how to move their men within it. The soldiers at Dargo performed their duty to the best of their abilities. The system which produced them is to blame for their failure, as are the authorities which allowed for the continuation of that system even beyond the conflict's end. The operational commanders sent to that theater were essentially set up to do poorly there. The commanders who did finally end that conflict were able to do so in part thanks to their recognition of the changes that were needed, but also in part because of unique circumstances within their then fragmenting enemy.

If the loss of the Crimean War had a major impact on the Russian military, it is not evident from their actions in Central Asia. For in that theater they behaved as they always had, maintaining adherence to Napoleonic warfare. Technological advances, finally implemented almost 20 years after defeat in Crimea, served only to increase the 
capacity to which Russian officers could pursue Napoleonic tactics in a Central Asian theater. There, the Russians encountered a terrain and an enemy that allowed them to implement the full Napoleonic system in everything from the application of firepower and movement to logistics. It is not that the Russian military had changed significantly from when it had been engaged in the Caucasus. Rather, the landscape had changed into one that enabled the Russians to practice a form of warfare at which they were already proficient. Because of this, the conquest of Central Asia would take a fraction of the time it had taken the Russians to conquer the Caucasus, a geographically much smaller area. The Central Asians learned to fear the Russian ability to bring massive quantities of firepower to bear in flat terrain, and had no natural defenses to take advantage of, besides deserts, which were the true challenge for the Russians in the theater.

The Russian military's inability to learn is often referenced in scholarly works, and Baumann notes the Russian military's lack of institutional capacity to codify lessons learned in war. ${ }^{287}$ He states that this continued until WWI, where one of the largest Russian armies ever assembled would be thoroughly defeated. It seems quite possible that the Russian military's fervent maintenance of old ideas and tactics seriously impacted the course of Russian history, as a nation which built several of history's most significant empires with military force. Had they been better able to learn from their operational past, and to incorporate knowledge gained under fire, the Russian military may have fared significantly into the twentieth century.

287 Baumann, Russian Soviet Unconventional Wars, 77. 


\section{Bibliography}

Arnold, James R. "A Reappraisal of Column versus Line in the Peninsular War." The Journal Military History 68, 2 (2004): 535-552.

Baddeley, John F. The Russian Conquest of the Caucasus. New York: Russell \& Russell, 1969.

Baumann, Robert F. "Russian-Soviet Unconventional Wars in the Caucasus, Central Asia, and Afghanistan." Leavenworth Papers: Combat Studies Institute, US Army Command and General Staff College 20 (1993).

Biloh, I.S. Finansy Rossii XIX Stoletiia: Istoriia Statistika, Tom I [Finances of Russia in the Nineteenth Century: History and Statistics, Volume I]. Saint Petersburg: 1882.

Biloh, I.S. Finansy Rossii XIX Stoletiia: Istoriia Statistika, Tom 2 [Finances of Russia in the Nineteenth Century: History and Statistics, Volume II]. Saint Petersburg: 1882.

Broxup, Marie. The North Caucasus Barrier: the Russian Advance towards the Muslim World. London: Hurst, 1992.

Bushnell, John. "The Tsarist Officer Corps: 1881-1914." The American Historical Review 86, 4 (1981): 753-780.

Curtiss, John Shelton. The Russian Army under Nicholas I, 1825-1855. Durham, N.C.: Duke University Press, 1965.

Curtiss, John Shelton. Russia's Crimean War. Durham, N.C.: Duke University Press, 1979. 
Delafield, Maj. Richard. Report on the Art of War in Europe in 1854, 1855, and 1856. From his Notes and Observations Made as a Member of a Military Commission to the Theater of War in Europe. Washington DC: USA Congress.

Delvig, N. I. "Vospominaniia ob Ekspeditsii v Dargo [Memories of Expedition to Dargo]" in Voennyॅ Sbornik 7 (1864): 16-20.

Dondukov-Korsakov, A. M. "Moi Vospominaniia [My Memories]." In Starina i Novizna: Istoricheskiŭ Sbornik, Book 6, 75-119. Saint Petersburg: Tipografiia M. Stasiulevicha, 1908.

Doyle, Peter. Fields of Battle: Terrain in Military History. New York: Springer, 2002. Dyke, Carl Van. Russian Imperial Military Doctrine and Education: 1832-1914. New York: Greenwood Press, 1990.

Eklof, Ben, and John Bushnell. "Miliutin and the Balkan War." In Russia's Great Reforms 1855-1881, 139-156. Indiana: Indiana University Press, 1994.

Ermolov, A. P. "Letter to M. S. Vorontsov, 19 June." Russkiü Arkhiv 2 (1890): 161-214.

Gaiman, V. A. "Vospominaniia V. A. Gaumana [Memories of V.A. Gaiman]" in Kavkazskiü Sbornik 3 (1879): 366-373.

Gammer, Moshe. Muslim Resistance to the Tsar: Shamil and the Conquest of Chechnia and Daghestan. London: F. Cass, 1994.

Glinoetskii, Lt. Gen. N.P. Istoriia Russkogo General'nogo Shtaba: Tom II, 1826-1855 [History of Russian General Staff, Volume II]. Saint Petersburg: Military Printing House, 1894.

Gorchakov, N. "Ekspeditsiia v Dargo: Iz Dnevnika Ofitsera Kurinskogo Polka, 1845 [Expedition to Dargo: From the Diary of the Officer of Koureen Regiment, 
1845]," Journal Zvezda 6 (1997): 79-90.

Hofschroer, Peter. Prussian Staff and Specialist Troops 1791-1815. Germany: Osprey, 2003.

Ignatiev, N. P. and John L. Evans, trans. Mission of N.P Ignatiev to Khiva and Bukhara in 1858. Newtonvill, MA: Oriental Research Partners, 2002.

Kagan, Frederick W., and Robin D. S. Higham. "Russia's Small Wars, 1805-1861." In The Military History of Tsarist Russia, 131-135. New York: Palgrave, 2002.

Kolokoltsov, D. G. "Dzhizak do Khivy, Pokhodnyı̌ Dnevnik Polkovnika Kolokol’tsova: Ekspeditsiia v Khivu v 1873 Godu [From Dzhizak to Khiva, Field Diary of Colonel Kolokotsov: Expedition to Khiva in 1873]." Voennyı̆ Sbornik 8 (1873): 19-71.

Kurlak, Charles C. "The Strategic Corporal: Leadership in the Three Block War." Marines Magazine (1999): 18-23.

Lisitsyna, G.G. "Vospominaniia Neizvestnogo Uchastnika Darginskoŭ Ekspeditsii 1845. Darginskaia Ekspeditsiia 1845 [The Memories of an Unknown Participant of the Dargo Expedition, 1845. Expedition to Dargo in 1845]" Journal Zvezda 6 (1996): 66-78.

MacGahan, J. A. Campaigning on the Oxus, and the Fall of Khiva. New York: Harper \& Brothers, 1874.

MacKenzie, David. The Lion of Tashkent: The Career of General M.G. Cherniaev, USA: University of Georgia Press, 1974.

Maksheev, A. I. Puteshestviia po Kirgizskim Stepiam i Turkestanskomu Kraiu [Journeys in Kirgiz Steppes and Turkestan Region]. Saint Petersburg: Voennaia Tipografiia 
v Zdanii Glavnogo Shtaba, 1896.

Maksheev, I. A. Istoricheskiu Obzor Turkestana [Historical Review of Turkestan]. Saint Petersburg: 1873.

Marshall, Alex. The Russian General Staff and Asia, 1800-1917. New York: Routledge, 2006.

Mayzel, Matitahu. "The Formation of the Russian General Staff: 1880-1917, A Social Study." Cahiers du Monde russe et soviatique 16, 3 (1975): 297-321.

McConachy, Bruce. "The Roots of Artillery Doctrine: Napoleonic Artillery Tactics Reconsidered." The Journal of Military History 65 (2001): 617-640.

Menning, Bruce. Bayonets before Bullets: the Imperial Russian Army, 1861-1914. Bloomington: Indiana University Press, 1992.

Muir, Rory. Tactics and the Experience of Battle in the Age of Napoleon. New Haven: Yale University Press, 2000.

Nicholas I, "Zapiska Imperatora Nikolaia I o Voennykh Deŭstviiakh na Kavkaze [A Note by the Emperor Nicholas I on the Military Actions in the Caucasus]." Russkaia Starina XLVIII, 10-12 (1885): 209-212.

Oye, David, Bruce Menning, and John W. Steinberg. "The Challenge of Reforming Imperial Russian General Staff Education, 1905-1909." In Reforming the Tsar's Army: Military Innovation in Imperial Russia from Peter the Great to the Revolution, 232-252. Cambridge: Cambridge University Press, 2004.

Paret, Peter, and Walter Pinter. "Russian Military Thought: The Western Model and the Shadow of Suvorov." In Makers of Modern Strategy: From Machiavelli to the Nuclear Age, 354-375. Oxford: Oxford University Press, 1986. 
Ray, Oliver Allen. "The Imperial Russian Army Officer." Political Science Quarterly 76 (1961): 576-592.

Reynolds, Michael. "Myths and Mysticism: A Longitudinal Perspective on Islam and Conflict in the North Caucasus." Middle Eastern Studies 1 (2005): 31-54.

Roerich, N. "Letter to his father, 5 April 1873." Dokumenty Russkoi Istorii 4 (2002): 1522.

Roy, Kaushik. The Army in British India from Colonial Warfare to Total War 1857-1947. London: Bloomsbury, 2013.

Saranchov, E. S. Khivinskaia Ekspeditsiia 1873 Goda: Zapiski Ochevidtsa Sapera E. Saranchova [Khivan Expedition of 1873: Notes of the Eyewitness Saper E. Saranchov]. Saint Petersburg: Typ. F. Sushchinskii, 1874.

Tucker, Albert V. "Army and Society in England 1870-1900: A Reassessment of the Cardwell Reforms." Journal of British Studies 2, 2 (1963): 110-141.

Von Hille, Julius Friedrich, Helga Doblin, and Mary C Lynn. The American Revolution, Garrison Life in French Canada and New York: Journal of an Officer in the Prinz Friedrich Regiment. Westport CT: Greenwood Publishing Group, 1993.

Vorontsov, M. S. "Letter to A. P. Ermolov, January 1845." Russkiu Arkhiv 2 (1890): 161214.

War Office, Infantry and Cavalry to Wear their Hair Queued. London: The National Archives.

Zaionchkovskii, A. M. Vostochnaia Voŭna: 1853-1856, Tom 1 [Eastern War: 1853-1856, Volume 1]. 1907. Reprint, Saint Petersburg: Print Polygon, 2002. 
Zelkina, Anna. In Quest for God and Freedom: Sufi Responses to the Russian Advance in the North Caucasus, New York: NYU Press, 2000. 